\title{
Carbonate and elemental accumulation rates in arid soils of mid-to-late Pleistocene outwash terraces, southeastern Wind River Range, Wyoming, USA
}

\author{
Dahms, Dennis ; Egli, Markus
}

\begin{abstract}
An important result of the past few decades of soil-geomorphic research is the awareness of the major role of dust and related carbonate precipitates in arid soils. The temporal evolution of soils developed on outwash terraces is still a matter of debate particularly regarding the type of evolution: progressive evolution and constant rates vs complex and/or interval-accumulation rates (progressive or regressive evolution possible). Soils on a chronosequence of outwash terraces just outside and downstream of canyon mouths of the Wind River Range (USA) were analysed for carbonate accumulation, organic carbon and poorly-crystalline pedogenetic oxyhydroxides stocks and pathways of chemical weathering. The soils and their carbonate stocks in the fine earth fraction $(<2 \mathrm{~mm})$ can be used as a relative dating tool and appear to correlate with regional glacial chronostratigraphy [Pinedale (c. 20 ky), Bull Lake (with two different units around 160 and $260 \mathrm{ky}$ ) and Sacagawea Ridge (c. $660 \mathrm{ky}$ )]. Carbonate stocks of soils on these terraces increase with increasing soil age, but at generally decreasing rates. A quasi-steady state situation, however, was not reached before $1 \mathrm{My}$. The time-split approach showed that CaCO3 accumulation rates were the highest during marine isotope (MIS) cold stages (2.13 g CaCO3/m2/y), presumably due to a sparse vegetation cover during MIS2 (Pinedale) and 8 (lower Bull lake). Compared to organic carbon (c. 8-10 kg Corg/m2), the inorganic carbon stocks of the fine earth fraction were much higher (c. $60 \mathrm{~kg}$ Cinorg $/ \mathrm{m} 2$ ). Although the dominant pedogenic process here appears to be carbonate accumulation, chemical weathering and elemental leaching also are significant. Weathering data were obtained using immobile elements and rare earth elements (REE) as tracers. Chemical weathering and related leaching were particularly notable for $\mathrm{Na}$ originating from plagioclase. In addition, pedogenetic $\mathrm{Al}$ and $\mathrm{Mn}$ oxyhydroxides accumulate (220 and $32 \mathrm{~g} / \mathrm{m} 2$, respectively, after $660 \mathrm{ky}$ ). These form at relatively low rates, however, when compared to moister and cooler conditions at higher altitudes in the Wind River Range. Due to the dry climate under which the terrace soils formed (annual precipitation $32 \mathrm{~cm} / \mathrm{yr}-1$ ), weakly crystalline and amorphous Fe-oxyhydroxide is rapidly transformed into crystalline forms (hematite) over time. Consequently, the stocks of weakly crystalline and amorphous Fe-oxyhydroxide was significantly lower in the $660 \mathrm{ky}$ soils $(50 \mathrm{~g} / \mathrm{m} 2)$ than in the Holocene soils $(1000 \mathrm{~g} / \mathrm{m} 2)$. The development of soils on Quaternary outwash terraces in this region is controlled through the rates of aeolian influx over time as modified by glacial/interglacial climate variations rather than by moisture availability. Consequently, carbonate accumulation rates in these soils are 'influx limited' rather than 'moisture limited'.
\end{abstract}

DOI: https://doi.org/10.1016/j.chemgeo.2015.12.006

Posted at the Zurich Open Repository and Archive, University of Zurich

ZORA URL: https://doi.org/10.5167/uzh-135071

Journal Article

Accepted Version 


\section{(2) $\odot \otimes \Theta$}

The following work is licensed under a Creative Commons: Attribution-NonCommercial-NoDerivatives 4.0 International (CC BY-NC-ND 4.0) License.

Originally published at:

Dahms, Dennis; Egli, Markus (2016). Carbonate and elemental accumulation rates in arid soils of mid-tolate Pleistocene outwash terraces, southeastern Wind River Range, Wyoming, USA. Chemical Geology, 446:147-162.

DOI: https://doi.org/10.1016/j.chemgeo.2015.12.006 
1 Carbonate and elemental accumulation rates in arid soils of mid-to-late

2 Pleistocene outwash terraces, southeastern Wind River Range, Wyoming, USA

4 Dennis Dahms ${ }^{1}$, Markus Egli ${ }^{2} *$

5

$6 \quad{ }^{1}$ Department of Geography, University of Northern Iowa, Cedar Falls, USA

${ }^{2}$ Department of Geography, University of Zurich, CH-8057 Zurich, Switzerland

(

(1)
*Corresponding author. Tel.: +41 4463551 14; fax: +41 446356848.
1 E-mail address: markus.egli@geo.uzh.ch (M. Egli).

(3)

\section{Abstract}

An important result of the past few decades of soil-geomorphic research is the awareness of the major role of dust and related carbonate precipitates in arid soils. The temporal evolution of soils developed on outwash terraces is still a matter of debate particularly regarding the type of evolution: progressive evolution and constant rates vs complex and/or interval-accumulation rates (progressive or regressive evolution possible). Soils on a chronosequence of outwash terraces just outside and downstream of canyon mouths of the Wind River Range (USA) were analysed for 1 carbonate accumulation, organic carbon and poorly-crystalline pedogenetic oxyhydroxides stocks 2 and pathways of chemical weathering. The soils and their carbonate stocks in the fine earth fraction $3(<2 \mathrm{~mm})$ can be used as a relative dating tool and appear to correlate with regional glacial 4 chronostratigraphy [Pinedale (c. 20 ky), Bull Lake (with two different units around 160 and 260 ky) 5 and Sacagawea Ridge (c. $660 \mathrm{ky}$ )]. Carbonate stocks of soils on these terraces increase with 
increasing soil age, but at generally decreasing rates. A quasi-steady state situation, however, was not reached before $1 \mathrm{My}$. The time-split approach showed that $\mathrm{CaCO}_{3}$ accumulation rates were the highest during marine isotope (MIS) cold stages $\left(2.13 \mathrm{~g} \mathrm{CaCO}_{3} / \mathrm{m}^{2} / \mathrm{y}\right)$, presumably due to a sparse vegetation cover during MIS2 (Pinedale) and 8 (lower Bull lake). Compared to organic carbon (c. 8 $-10 \mathrm{~kg} \mathrm{C}$ org $/ \mathrm{m}^{2}$ ), the inorganic carbon stocks of the fine earth fraction were much higher (c. $60 \mathrm{~kg}$

$31 \mathrm{C}_{\text {inorg }} / \mathrm{m}^{2}$ ). Although the dominant pedogenic process here appears to be carbonate accumulation, 32 chemical weathering and elemental leaching also are significant. Weathering data were obtained using immobile elements and rare earth elements (REE) as tracers. Chemical weathering and related leaching were particularly notable for $\mathrm{Na}$ originating from plagioclase. In addition, pedogenetic $\mathrm{Al}$ and $\mathrm{Mn}$ oxyhydroxides accumulate (220 and $32 \mathrm{~g} / \mathrm{m}^{2}$, respectively, after $\left.660 \mathrm{ky}\right)$. These form at relatively low rates, however, when compared to moister and cooler conditions at higher altitudes in the Wind River Range. Due to the dry climate under which the terrace soils formed (annual precipitation $32 \mathrm{~cm} / \mathrm{yr}^{-1}$ ), weakly crystalline and amorphous Fe-oxyhydroxide is rapidly transformed into crystalline forms (hematite) over time. Consequently, the stocks of weakly crystalline and amorphous Fe-oxyhydroxide was significantly lower in the $\sim 660 \mathrm{ky}$ soils $\left(50 \mathrm{~g} / \mathrm{m}^{2}\right)$ than in the Holocene soils $\left(1000 \mathrm{~g} / \mathrm{m}^{2}\right)$.

The development of soils on Quaternary outwash terraces in this region are controlled through the rates of aeolian influx over time as modified by glacial/interglacial climate variations rather than by moisture availability. Consequently, carbonate accumulation rates in these soils are 'influx limited' rather than 'moisture limited'.

\section{Introduction}


Pleistocene climate cycles have driven multiple glacial-interglacial episodes in most middle-to-high

51 latitude mountain regions of the world. In North America, the U.S. Rocky Mountains consist of numerous mountain ranges that contain records of multiple glacial episodes (e.g., Richmond 1986; Dahms 2004a). The Greater Yellowstone Ecosystem occupies a central role in our conception of Pleistocene glacial history since it has the type localities for the entire Pleistocene glacial succession identified in the U.S. Rocky mountains (see Richmond 1986; Dahms 2004a; Pierce 2004). The Wind River Range (WRR) occupies the southern-most extent of the Yellowstone Ecosystem and was the locus of most early research into the Pleistocene glacial succession of the region (Blackwelder 1915; Richmond 1948, 1964, 1986; Mears, 1974). Most alpine valleys here were occupied by glaciers multiple times (Blackwelder 1915; Richmond 1973; Dahms 2004b). Morphostratigraphic evidence shows a minimum of four major glacial advances occurred here over the past $~ 1$ My (Richmond, 1987; Hall and Shroba, 1995; Hall and Jaworowski, 1999; Dahms, 2004b).

An important result of the past few decades of soil-geomorphic research is the awareness of the major role of dust in arid (desert) and semi-arid regions of the world (e.g. Sauer et al., 2007; Muhs 2013, Muhs et al. 2014). In the southwestern U.S. the influx of calcareous dust is central to the genesis of calcic and petrocalcic horizons in desert soils (Gile et al., 1981; Reheis et al., 1992; McFadden, 2013). Those soils that develop beneath desert pavements of the arid southwestern U.S. form in parent materials increasingly composed of entrapped dust that is subsequently translocated below the pavement to 'build' the soil from above (McFadden, 2013).

Soils developed on Quaternary deposits of semi-arid (non-'desert') regions of the U.S. also exhibit significant contents of aeolian material (Colman and Pierce, 1986; Sorenson 1987; Reheis, 1988, 1990; Muhs et al., 1990; Reheis, 1990; Dahms 1993; Dahms and Rawlins 1996) as do soils of alpine regions of the western U.S. (Marchand 1970; Birkeland 1973; Williams 1973; Thorn and 
Darmody 1980; Boulding and Boulding 1981; Shroba and Birkeland 1983; Swanson 1985;

Birkeland et al. 1987; Litaor, 1987, 1988; Dixon, 1992; Muhs and Benedict, 2006).

We previously described soils developed on moraine chronosequences of the WRR and found clear aeolian signals in their particle size distributions, heavy mineral fractions and geochemical signatures (Dahms 1993, 2004b; Dahms and Rawlins 1996; Applegarth and Dahms 2001, 2004; Dahms et al., 2012). Few studies exist in this region, however, that describe soil chronosequences from the outwash terraces downstream of the moraine units. Soil characteristics are reported from terrace chronosequences of the Wind River in the central Wind River Basin upstream from the confluence of the Wind and Popo Agie rivers (Nettleton and Chadwick, 1991) and soils on the terraces of Rock Creek, a tributary of the Bighorn River are reported from the northern Big Horn Basin (Reheis, 1987, 1988, 1990). No previous data exists for tributary streams emanating from the glaciated valleys of the eastern slope of the Wind River Range.

In this study we report a suite of newly-developed chemical weathering data for a chronosequence of soils on terraces of the three forks of the Popo Agie River near Lander, Wyoming. These data will contribute further to the development of soil chronosequences and will function as relative-age tools for correlating Pleistocene terraces in this region to their corresponding moraine units (Dahms, 2010). In order to further develop evidence relating to the contribution of aeolian materials, and especially carbonate, to soil development over time on Quaternary alluvium in the Wind RiverYellowstone region (Hall, 1999), we describe a chronofunction for carbonate accumulation and try to derive, where possible, the corresponding interval accumulation rates (progressive or regressive evolution possible). Few data sets exist for long-term trends in production and accumulation of oxyhydroxides of $\mathrm{Fe}$ and $\mathrm{Al}$ in arid-lands soils such as these. Our results suggest that as weathering and pedogenesis proceeds over time, secondary mineral phases of $\mathrm{Fe}$ and $\mathrm{Al}$ form that initially have poorly/weakly crystalline characteristics, but develop strongly crystalline forms with time. Furthermore, disagreement exists as to whether such soils develop linearly and progressively or 
if/when a quasi-steady state situation is ever reached (cf. Reheis, 1990; Reheis et al., 1992; Landi et al., 2003).

\section{Study Region}

The study region is on the southeastern end of the Wind River Range, near Lander, Wyoming (Fig. 1). The drainages of the Popo Agie basin flow from the southernmost glaciated region of the range. The Popo Agie basin drains most of the alpine region of the southeastern Wind River Range (Fig. 1). All three tributaries (the North, Middle, and Little Popo Agie) were occupied by Pleistocene valley glaciers, resulting in the formation of a four-fold sequence of outwash terraces along each of these streams as presumed floodplain aggradation during each glacial maximum gave way to stream incision during the post-glacial period(s) (Vandenberghe, 2015).

The North Fork of the Popo Agie drains the Cirque of the Towers; the Middle Fork of the Popo Agie drains Deep Lakes, Ice Lakes, Stough Lakes, and Leg Lake basins; the Little Popo Agie drains the Silas and Christina Lake cirques (Fig. 1). The presence of well-preserved moraines near the mouths of their canyons indicates that the valleys of all three of the rivers were occupied by glaciers at least four times during the last $\sim 1 \mathrm{Ma}$ (Dahms 2004b and unpublished map data). We chose to study the Popo Agie basin because the outwash terraces (Fig. 2) are well-expressed and appear generally to correspond to previously-mapped terrace units along the Wind River (Chadwick et al., 1997; Hancock et al., 1999; Dahms 2010) to which the Popo Agie river grades (Fig. 1) and on which soils are previously described (Nettleton and Chadwick, 1991).

The Pleistocene terraces we studied are all within 5 miles of the mouth of their canyons (Fig. 2). All terraces but the Holocene unit (PB-13-1) are strath terraces (e.g., Bierman and Montgmery, 2014) formed as the rivers cut into the sedimentary units that crop out along the southeastern flank of the WRR (Fig. 2). Terraces along the Little Popo Agie River have slightly different sedimentary and 
soil parent material characteristics. These are inset into carbonate-bearing 'Redbeds' of the Red Peak/Chugwater formations (Picard, 1993), so the coarse gravels of granitic and sedimentary origin from the interior massif and inner canyon grade upward to clays, silts, and fine sand derived exclusively from the redbeds (Fig 2d,e). Consequently, the parent materials of the soils on the Little Popo Agie River terraces contain varying amounts of $\mathrm{CaCO}_{3}$ (see Table 1). The soil parent materials of the North and Middle Forks of the Popo Agie River are derived primarily from noncalcareous granitic alluvium (Table 1) from the interior of the Wind River Range and from outwash derived from upstream moraines (see Dahms, 2004a,b). The only terrace that contains fines derived from redbeds in our present sequences along the North and Middle forks is the terrace represented by sample GalPD (Fig. 2).

The climate of the lower slopes and piedmont of the eastern Wind River Range near Lander is classified as semi-arid (Köppen $B s k$ ) with a mean annual maximum temperature of $14^{\circ} \mathrm{C}$, a mean annual minimum temperature of $0^{\circ} \mathrm{C}$ and a MAT of $7^{\circ} \mathrm{C}$ (2015 US Climate Data). Mean annual precipitation at Lander is $320 \mathrm{~mm}$. All terrace sites of the study area are grassland/sagebrush steppe, with riparian areas adjacent to the streams. The terrace soils (Fig. 3) are classified in the U.S. taxonomic system as Aridisols and Inceptisols (Soil Survey Staff, 2014). The more well-developed soils can be classilfied as Petrocryids/Calcicryids and the less-developed soils as Haplocryids.

Age control for terraces in this study is provided by geomorphologic mapping, including relativeage relationships (Dahms unpublished maps), correlations with ${ }^{10} \mathrm{Be}$ and ${ }^{26} \mathrm{Al}$ boulder-surface exposure ages from local moraine units of the Wind River Range (Gosse et al., 2003; Fabel et al., 2004; Dahms, 2004b; Dahms and Egli, unpublished data) and correspondence to terraces and soils of the Wind River (Hancock et al., 1999; Hall and Jaworowski, 1999; Jaworowski, 1992; Nettleton and Chadwick, 1991). We also take into account the ages suggested for terraces along Rock Creek, a tributary to the Bighorn River in the northern Bighorn Basin (Reheis, 1987). The Bighorn River is the name assigned to the Wind River as it flows through the Bighorn Basin downstream of Wind 
149 River Canyon (Fig. 1). For purposes of this study, we assign the following tentative ages to the 150 Popo Agie terraces and soils: Holocene (5 ky \pm 3 ky; profile PB-13-1), Pinedale (20 ky \pm 4 ky; 151 profiles GalPD and RCT-2), 'lower' Bull Lake (160 ky \pm 30 ky; profiles LWS, RCT-3, GR-13-1), 152 'upper’ Bull Lake (260 ky \pm 30 ky; profiles RCT-4, SB, GR-2) and Sacagawea Ridge (660 ky \pm 80 153 ky; profiles RCT-5, PB-13-2). We associate these ages, respectively, with Marine Isotope Stages 1 $154-2-6-8$ and 16 . An additional numeric age to which we can correlate locally comes from a Lava 155 Creek ash deposit (c. 640 ky) reported by Jaworowski (1992) from the gravels of the highest 156 'airport' terrace at Lander, from which no soil is reported here (Fig. 2B).

\section{Materials and methods}

\subsection{Sampling strategy}

161 Soils were sampled and described from hand-dug pits on flat summit-shoulder positions using standard methods and horizon nomenclature (Fig. 3; Birkeland et al., 1991; Soil Survey Division Staff 1993). To obtain a detailed and long-term chronosequence, we sampled 11 terraces having an age of a few thousands of years (Holocene) to more than $600 \mathrm{ky}$. Profiles were dug to the C horizon when possible. About $2 \mathrm{~kg}$ of soil material per horizon were taken for the analyses (Hitz et al., 2002).

\subsection{Physical analyses}

169 Laboratory analyses of soil physical characteristics used standard techniques modified from Jackson 170 (1969), Klute (1986) and Singer and Janitsky (1986). Particle size-distribution of the $<2 \mathrm{~mm}$ 171 fraction was determined as weight percent (USDA scale) using the sieve-and-pipette method with 172 prior oxidation of organic matter by $30 \% \mathrm{H}_{2} \mathrm{O}_{2}$, removal of pedogenic carbonate via $0.5 \mathrm{~N} \mathrm{HCL}$ on 173 heat $\left(\sim 80^{\circ} \mathrm{C}\right)$ and is reported as weight percent (USDA grain-size scale). The bulk density (fine 
earth and soil skeleton) was estimated from corresponding horizons of previously-reported soils for which BD was determined from gravel-free paraffin-coated peds using an estimated gravel density of $2.6 \mathrm{~g} / \mathrm{cm}^{-3}$ (Dahms, 2002, 2004).

\subsection{Chemical analyses}

Oven-dried samples $\left(70{ }^{\circ} \mathrm{C}\right)$ were sieved to $<2 \mathrm{~mm}$ (fine earth) and homogenised with a sample separator (Rentsch PT 1000). Soil-pH (0.01 $\left.\mathrm{M} \mathrm{CaCl}_{2}\right)$ was determined using a soil:solution ratio of 1:2.5. Carbonates were determined by using two different techniques. One consisted in the dissolution of carbonates using $\mathrm{HCl}$. The results were then compared with total $\mathrm{Ca}$ and $\mathrm{Mg}$ concentrations obtained from XRF measurements. We performed an iterative speciation calculation with the XRF data based on elemental contents and presented as oxides or carbonates (and fitted to $100 \%$ as total sum) to determine $\mathrm{CaO}, \mathrm{CaCO}_{3}, \mathrm{MgO}$ and $\mathrm{MgCO}_{3}$ species. Organic $\mathrm{C}$ and $\mathrm{N}$ contents (determined in duplicate) of the soil were measured at $550{ }^{\circ} \mathrm{C}$ using a $\mathrm{C} / \mathrm{H} / \mathrm{N}$ analyser (Leco). The standard reference material is EDTA (Säntis Analytical, article no SA502092) having C = 41.09\%, $\mathrm{H}=5.52 \%, \mathrm{~N}=9.58 \%, \mathrm{O}=43.8 \%$ (measured values were $\mathrm{C}: 41.11 \pm 0.08 \% ; \mathrm{H}: 5.53 \pm 0.08 \%$; : $9.57 \pm 0.08 \%$, O: $43.79 \pm 0.08)$.

$\mathrm{Fe}, \mathrm{Al}$ and $\mathrm{Mn}$ concentrations were determined (in duplicate) after treatment with $\mathrm{NH}_{4}$-oxalate (buffered at pH 3; McKeague et al., 1971). The extracts were centrifuged for 8 minutes at $4000 \mathrm{rpm}$ and filtered (mesh size $0.45 \mu \mathrm{m}, \mathrm{S} \& \mathrm{~S}$, filter type 030/20). Element concentrations were measured using atomic absorption spectroscopy (AAnalyst 700, Perkin Elmer). The blank values measured (Fe: $-0.23 \pm 0.06 \mathrm{mg} / \mathrm{l} ; \mathrm{Al}:-0.04 \pm 0.8 \mathrm{mg} / \mathrm{l} ; \mathrm{Mn}:-0.005 \pm 0.004 \mathrm{mg} / \mathrm{l}$ ) were considered for the elemental concentrations. Element concentrations were furthermore controlled using standard addition (recovery $\geq 95 \%$ ). The oxalate treatment extracts both the weakly- and poorly crystalline phases and some of the organic phases, but normally does not dissolve the strong humus-metal complexes (Mizota and van Reeuwijk, 1989). A portion of each oxalate extraction was analysed for 
rare earth elements (REE) with an Agilent 8800 Triple Quadrupole (QQQ-ICP-MS). Prior to ICP-

200 MS analyses, standard solutions were prepared from SPEX multi-element plasma standard (Spex 201 CertiPrep, NJ, USA) at 0, 10, 50, 100, 500 and $1000 \mathrm{ppb}$ to derive calibration curves. Concentration of REEs were measured from standard solutions, reference material (CCRMP, REE-1), blank and soil samples. Repeated measurements of the standards showed that the precision error was less than $2048 \%$.

205 The total elemental content was determined by X-ray fluorescence. Soil material was milled to $<63$ $206 \mu \mathrm{m}$ in a tungsten carbide disc swing mill (Retsch ${ }^{\circledR}$ RS1, Germany). Powder samples (in duplicates) 207 of approximately $5 \mathrm{~g}$ material were analysed with an energy dispersive He-flushed X-ray 208 fluorescence spectrometer (ED-XRF, SPECTRO X-LAB 2000, SPECTRO Analytical Instruments, 209 Germany). The quality of the analyses was checked using a soil reference material (Reference Soil 210 Sample CCRMP SO-4, Canada Centre for Mineral and Energy Technology) with certified total 211 element concentrations. Element recovery and detection limits are given in Appendix A.

\subsection{Soil mineralogy}

214 We used XRD (X-ray diffraction) and DRIFT (Diffuse Reflectance Infrared Fourier Transform 215 spectroscopy) analyses to qualitatively describe the soils' mineralogical properties. An overview of 216 the mineral content in the fine silt and clay fraction $(<32 \mu \mathrm{m})$ was obtained by scanning randomly 217 oriented samples from 2 to $80^{\circ} 2 \theta$ with steps of $0.02^{\circ} 2 \theta$ at $10 \mathrm{~s}$ intervals using a Bruker AXS D8 218 Advance $(\mathrm{CuK} \alpha)$.

219 DRIFT-spectra (Bruker, Tensor 27) were recorded from 4000 to $250 \mathrm{~cm}^{-1}$ using a powder 220 containing $30 \mathrm{mg}$ of sample (10\% of the total weight) and $270 \mathrm{mg} \mathrm{KBr}(90 \%$ of the total weight).

221 Prior to measurement, the samples were again oven-dried at $60^{\circ} \mathrm{C}$. The FT-IR spectra were 222 interpreted using the OPUS 6.5 software. 
225 Weathering characterization is based on the calculation of elemental losses from soil or sediment profiles. Relative elemental losses can be calculated using the open-system mass transport function $\tau_{j, w}($ Chadwick et al., 1990):

$$
\tau_{j, w}=\left(\frac{C_{j, w} \cdot C_{i, p}}{C_{i, w} \cdot C_{j, p}}\right)-1
$$

231 where $i$ denotes the immobile element $(\mathrm{Ti}), C_{j, p}(\mathrm{~g} / \mathrm{kg})$ is the concentration of element $j$ in the unweathered parent material and $C_{j, w}$ is the concentration of element $j$ in the weathered product $233(\mathrm{~g} / \mathrm{kg})$.

234 Mourier et al. (2008) showed that rare earth element (REE) geochemistry of lacustrine sediments and soils is useful for reconstructing the history of landscape evolution. Normalised REE patterns may provide a tracer of the degree of weathering of materials. In contrast to Mourier et al. (2008), the REE concentrations were not normalised to a chondritic reference standard (Sun and McDonough, 1989) but to the parent material of the soils to better facilitate the interpretation of weathering behaviour (cf. Scarciglia et al., 2009, 2011) between sites. Normalisation against a common reference helps to identify subtle fractionations and anomalies in elemental abundances

241 (Mourier et al., 2008). Only a portion of the REEs could be measured using XRF (La, Ce, Pr, Nd and Sm). These elements were compared to the oxalate extractable fraction. In addition, the sample composition (total concentration) was also compared to a set of major and trace elements of the

244 parent material. This set includes $\mathrm{SiO}_{2}, \mathrm{TiO}_{2}, \mathrm{Al}_{2} \mathrm{O}_{3}, \mathrm{Fe}_{2} \mathrm{O}_{3}, \mathrm{CaO}, \mathrm{MgO}, \mathrm{Na}_{2} \mathrm{O}, \mathrm{K} 2 \mathrm{O}, \mathrm{MnO}, \mathrm{V}, \mathrm{Cr}$, $245 \mathrm{Ni}, \mathrm{Cu}, \mathrm{Zn}, \mathrm{Rb}, \mathrm{Sr}, \mathrm{Y}, \mathrm{Zr}, \mathrm{Nb}, \mathrm{Ba}, \mathrm{Pb}$, Th und $\mathrm{U}$.

\subsection{Stocks calculation and accumulation of pedogenetic products}

248 Organic $\mathrm{C}$ and $\mathrm{N}$ stocks were calculated according to the following equation: 


$$
E_{\text {stock }, i}=\sum_{a=1}^{n} E_{i} \Delta z_{i} \rho_{i}(1-R M)
$$

250 where $E_{\text {stock }}$ denotes the abundance $\left(\mathrm{kg} / \mathrm{m}^{2}\right)$ of element $i, E_{i}$ is the element concentration $(\mathrm{kg} / \mathrm{t}), \Delta z_{i}$

251 the thickness of layer $i(\mathrm{~m}), \rho_{i}=$ soil density $\left(\mathrm{t} / \mathrm{m}^{3}\right)$ and $R M$ the volumetric mass proportion of rock

252 fragments.

253 To estimate the amount of pedogenically formed Fe, Al and Mn in soils, the concentrations of each 254 compound in the soil column is compared to the parent material (or the layer with the least 255 concentration). Using the concept of immobile elements, gains and losses of $\mathrm{Fe}, \mathrm{Al}$ and $\mathrm{Mn}$ are 256 derived using equation (3)

$$
M_{j, w}=M e_{j, w}\left(\frac{\tau_{j, w}}{1+\tau_{j, w}}\right) \Delta z_{w} \rho_{w}(1-R M)
$$

With $n$ soil layers, the mass accumulation of the element $j$ is given by:

$$
M_{j, w}\left(\Delta z_{w}\right)=\sum_{a=1}^{n} M e_{j, w}\left(\frac{\tau_{j, w}}{1+\tau_{j, w}}\right) \rho_{w}(1-R M) \Delta z_{w}
$$

where $\tau_{j, w}$ again corresponds to the mass transport function and $\Delta z$ to the weathered equivalent of 261 the columnar height.

The accumulation of inorganic $\mathrm{C}$ was calculated as the overall stock at the position where the parent material did not contain any carbonates. Soils on all the Little Popo Agie terraces (RCTs) and the

264 GalPD terrace of the North Fork, however, contained small amounts of carbonate in the parent 265 materials. In this case, accumulation (or losses) of inorganic $\mathrm{C}$ were calculated using the approach 266 given in equations 3 and 4.

\section{Results}

\subsection{General characteristics of the terrace soils}

271 Except for profile RCT2, all investigated soils contain considerable contents of gravel that usually increases with increasing depths (Table 2). The soil texture is mostly clay loam, loam or silt loam. 
In some cases (particularly $\mathrm{C}$ horizon), the texture can be characterised as sand, loamy sand or 274 sandy (clay) loam. Soil thickness (A+B horizon) varies between 40 and about $150 \mathrm{~cm}$. Due to the presence of carbonates the soils are all neutral or slightly alkaline (often between 7 and 8; Table 3). Only the soils at PB-13-1 and GR-13-2 exhibit slightly acidic conditions in their upper horizons. In several profiles, the $\mathrm{B}, \mathrm{BC}$ and/or $\mathrm{C}$ horizons contain large accumulations of inorganic carbon. The parent material at the RCT and GalPD sites contained some carbonates $(13-22 \mathrm{~g} / \mathrm{kg}$ inorg. C). With increasing age of the terraces the average concentration of inorganic carbon increases in each accumulation horizon (from a few $\mathrm{g} / \mathrm{kg}$ to about $82 \mathrm{~g} / \mathrm{kg}$ ) and also the thickness of the carbonaterich subsoil horizons (Table 3; Figs. 3 and 4).

In contrast, the concentration of organic carbon shows no trend with age. The influence of organic carbon on total $\mathrm{C}$ is manifested almost exclusively in the A horizons. With increasing soil depth the overwhelming proportion of carbon exists in an inorganic form. The $\mathrm{C}_{\text {org }}$ content in $\mathrm{A}$ horizons is not particularly high but is found to a considerable depth. Org. $\mathrm{C} / \mathrm{N}$ ratios (Table 3) decrease with increasing soil depth and exhibit low values in all profiles, particularly in the subsoils.

Pedogenic oxyhydroxides are present in all profiles. $\mathrm{Fe}(\mathrm{ox}), \mathrm{Al}(\mathrm{ox})$ and $\mathrm{Mn}(\mathrm{ox})$ usually decrease with increasing soil depth. In surface soils, oxyhydroxides appear to be enriched passively due to the accumulation of carbonates in the $\mathrm{B}, \mathrm{BC}$ or $\mathrm{C}$ horizon, the weathering of silicate minerals, or blown in as part of the aeolian influx..

\subsection{Rare earth elements and normalised elemental contents}

293 We used major and trace elements to assess pathways of chemical weathering and to assess aeolian 294 additions to the terrace soils. To compensate for the dilution effect of accumulated $\mathrm{CaCO}_{3}$, the considered elements were referred to $\mathrm{Zr}$ (Fig. 5). For several components (that are not related to carbonates), the $20 \mathrm{ky}$ terrace had the higher values and the $660 \mathrm{ky}$ terrace soils (particularly in the

297 subsoil these differences are pronounced; Fig. 5). Although the terrace soils apparently have 
received a considerable input of aeolian carbonates over time, some $\mathrm{Mg}, \mathrm{Ca}$ and $\mathrm{K}$ has been lost due

299 to weathering of primary silicates. $\mathrm{Mn}$ is depleted in the subsoil but enriched in the A-horizon. In 300 addition, a substantial portion of $\mathrm{Na}$ has been leached in the subsoil. Most trace elements are 301 depleted but the signal is quite variable. Finally, Sr has accumulated with time in both A and B(k) 302 horizons. As Sr is strongly linked to the behaviour of $\mathrm{Ca}$ (and therefore carbonates) it indicates a 303 more or less continuous aeolian input and translocation of carbonates within the soils.

304 The values of the normalised REEs show that the oxalate-extractable fraction (and thus the fraction 305 found in the weathering products) is three to four orders of magnitude lower than the total REE 306 content. The normalized ratios (with respect to the total contents) are slightly lower in the B 307 horizons than in the A horizons. La, Ce and $\mathrm{Nd}$ are enriched over time in the A horizon but depleted 308 in the $\mathrm{B}(\mathrm{k})$ horizons. Similarly, the soils older than 20 ky show a slight accumulation of oxalate309 extractable REEs in the A horizon and a depletion in the $\mathrm{B}(\mathrm{k})$ horizons. This depletion (total and 310 oxalate-extractable fraction) probably is related to a dilution effect due to the accumulation of 311 carbonates in the subsoil.

312 All REE ratios are distinctly lower in the $\mathrm{B}(\mathrm{k})$ horizons when compared to the A horizons. As 313 byproducts of weathering, REEs are found to be incorporated into or adsorbed on secondary 314 minerals (clay minerals, pedogenic oxyhydroxides; Laveuf and Cornu, 2009). In the B horizons, the 315 decrease of oxalate-extractable $\mathrm{La}, \mathrm{Ce}, \mathrm{Pr}, \mathrm{Nd}$ and $\mathrm{Sm}$ with time apparently is caused by dilution 316 owing to the accumulation of carbonates in the Bk horizon. Due to weathering of soil minerals, the 317 normalised oxalate-extractable REE fraction increases in A horizons with time (Fig. 6).

318 To study possible aeolian additions to soils, it is helpful to use chemically immobile elements. We 319 chose the elements $\mathrm{Ti}, \mathrm{Zr}, \mathrm{Nb}, \mathrm{Ce}$, and $\mathrm{Y}$, all of which have a relatively high ionic potential and are 320 considered to be chemically immobile under most near-surface environments (Hutton, 1977; Taylor 321 and McLennan, 1985; Muhs and Benedict, 2006). According to Muhs and Benedict (2006), Tb and $322 \mathrm{Nb}$ are found in ilmenite, rutile, anatase, titanomagnetite, sphene, and biotite. $\mathrm{Zr}$ is mostly present in 
zircon, although $\mathrm{Zr}$ may also be found in other minerals (e.g. zirconolite). The REEs Ce and $\mathrm{Y}$ are

324 related to a wide variety of minerals such as phyllosilicates (adsorption on e.g., micas, chlorite, 325 other clay minerals), sphene, amphiboles and apatite (Muhs and Benedict, 2006). Ti/Zr, Ti/Nb and $326 \mathrm{Ce} / \mathrm{Y}$ ratios measured in the A horizons, the horizons with carbonate accumulation $(\mathrm{Bk}, \mathrm{CBk}, \mathrm{Ck})$ 327 and the $\mathrm{C}$ horizons show a wide overlap (Fig. 7). The ratios demonstrate that the major chemical 328 background of the various soil horizons does not vary appreciably and suggests that aeolian 329 materials, which should be most concentrated in A and B horizons compared to C horizons, 330 originate predominantly from local sources (e.g. vegetation free proglacial areas or sparsely 331 vegetation-covered areas (Dahms, 1993; Dahms and Applegarth, 2001, 2004). Based on the above 332 relations among the chemical and mineralogical soil properties, the Popo Agie terrace surfaces 333 apparently have received significant amounts of dust that has led to, among other factors, an 334 accumulation of pedogenic carbonate in the profiles over time.

\subsection{Soil mineralogy}

The primary minerals in the soil profiles are quartz, different types of feldspars, mica and calcite together with 1:1 (kaolinite) and 2:1 (vermiculite) phyllosilicates (Table 4); these mineral suites are consistent with the granitic nature of the local outwash material. 2:1:1 minerals are mostly absent. In addition, the parent materials for soils on the Little Popo Agie and the GalPd (North Fork)

341 terraces contain calcite from the local redbeds. Hematite content also appears to increase with soil 342 age (Table 4, Fig. 8).

4.4. Accumulation of inorganic and organic carbon and pedogenetically formed $F e_{o x}, A l_{o x}$ and $M n_{o x}$

345 As noted above, the amount of inorganic carbon progressively increases in the soils with age (Fig. 346 9). This trend exhibits a logistic-curve form: during the first $20 \mathrm{ky}$ the increase is moderate, a 347 stronger increase is seen between $20 \mathrm{ky}$ and $250 \mathrm{ky}$, and the ratio again slows for the older soils. At 
the end of the sequence, a considerable amount of inorganic $\mathrm{C}$ is stored in the soil with average

349 values of about $60 \mathrm{~kg} / \mathrm{m}^{2}$ in the fine earth fraction. With the exception of the $20 \mathrm{ky}$ terrace soils 350 (where a higher stock was measured with about $14 \mathrm{~kg}$ org. $\mathrm{C} / \mathrm{m}^{2}$ ), the organic carbon stocks were in 351 the range of $8-10 \mathrm{~kg} / \mathrm{m}^{2}$. In contrast to inorganic $\mathrm{C}$, the organic carbon stocks did not change over 352 time.

353 The pedogenic stocks of $\mathrm{Fe}_{\mathrm{ox}}, \mathrm{Al}_{\mathrm{ox}}$ and $\mathrm{Mn}_{\mathrm{ox}}$ all change considerably with time (Fig. 10) but the 354 time-trends are not uniform. The $\mathrm{Al}_{\mathrm{ox}}$ and $\mathrm{Mn}_{\mathrm{ox}}$ abundances increase until c. $250 \mathrm{ky}$ and then 355 decrease to $660 \mathrm{ky}$. In contrast, the $\mathrm{Fe}_{\mathrm{ox}}$ stocks in the soils steadily decrease with increased terrace 356 age, with a marked loss of $\mathrm{Fe}_{\mathrm{ox}}$ stocks between 5 and $20 \mathrm{ky}$ The stored amount at the start of the 357 time sequence was about $1 \mathrm{~kg} / \mathrm{m}^{2}$; by c. $600 \mathrm{ky}$ the $\mathrm{Fe}_{\mathrm{ox}}$ stocks decrease to only about $50 \mathrm{~g} / \mathrm{m}^{2}$.

\section{Discussion}

\subsection{Carbonate accumulation}

362 Gile et al. $(1966,1981)$ and Machette (1985) provide baseline data concerning the development of 363 arid-lands soils emphasizing the systematic accumulation of pedogenic carbonate with time on 364 chronosequences of geomorphic surfaces in the southwestern U.S. These authors showed that the 365 calcium contained in pedogenic carbonate of arid-lands soils can derive directly from the parent 366 materials, minerals present in the soil, or from atmospheric additions. As Muhs (2013) indicates, 367 this type of soil development has been recognised in many desert regions of the world where the 368 moisture balance is such that pedogenic carbonates are not fully leached from soil profiles but 369 accumulate slowly, particularly in the subsoil. Where the geologic substrate provides little $\mathrm{Ca}$, the majority of the $\mathrm{Ca}$ in pedogenic carbonate derives essentially from aeolian input (Gile et al., 1981;

371 Muhs, 2013). According to McFadden (2013), virtually all calcium in pedogenic carbonate in the 372 southwestern U.S. is derived from calcium-bearing dust that primarily accumulates in a very 
common horizon of arid land soils - the calcic horizon.

The work of McFadden (2013), Reheis (1990; Reheis et al., 1992; Reheis and Kihl, 1995) and Machette (1985) effectively demonstrates the regional importance of carbonate-rich aeolian influx to geomorphic surfaces and the soils that develop in them. Soils reported from the Kyle Canyon fans of Nevada (Reheis et al., 1992), the grassland and forests soils of Saskatchewan (Landi et al., 2003) and various geomorphic surfaces of New Mexico and Utah (Machette, 1985) illustrate the importance of regional carbonate accumulations in soils over time and allow us to generally compare our results to soils developed in other arid regions of the U.S. More locally, Reheis' work (1987) along Rock Creek in the northern Big Horn Basin allows us to compare our results with a similar glacio-fluvial sequence in an adjacent area of the Middle Rocky Mountains.

The oldest soils of the Popo Agie River chronosequence are older than those in Nevada (where stocks were available; the oldest Kyle Canyon soil was $>800 \mathrm{ka}$ ) or Saskatchewan, yet our $\mathrm{CaCO}_{3}$ stocks were mid-range between these regions $\left(470 \mathrm{~kg} \mathrm{CaCO} / \mathrm{m}^{2}\right.$ compared to $630 \mathrm{~kg} / \mathrm{m}^{2}$ in the Kyle Canyon fan of Nevada and $134-165 \mathrm{~kg} / \mathrm{m}^{2}$ in Saskatchewan).

Aeolian influx is the dominant mechanism for the carbonate accumulation over time in the soils developed in the Popo Agie terraces. Calcium from atmospheric deposition enters the soil when it is wetted and moves downward; calcium carbonate is precipitated on drying. Consequently, carbonates tend to accumulate in the lower part of the zone that is wetted (Gile et al., 1981).

Reheis et al. (1992) reported that pedogenic $\mathrm{CaCO}_{3}$ accumulated in the arid soils of southern Nevada at a rate of $3-15 \mathrm{~g} / \mathrm{m}^{2} / \mathrm{y}$. Landi et al. (2003) derived $\mathrm{CaCO}_{3}$ accumulation rates from the grassland and forests soils of Saskathewan in the range of 8.3 to $14.3 \mathrm{~g} / \mathrm{m}^{2} / \mathrm{y}$. In soils of the Rock Creek terraces, Reheis (1987) reported $\mathrm{CaCO}_{3}$ accumulation rates from 0.11 to $5.5 \mathrm{~g} / \mathrm{m}^{2} / \mathrm{y}$, depending on distance from the range front. The values reported for southern Nevada and Saskatchewan are clearly above those of the present study, but the accumulation rates for the Popo Agie terrace chronosequence $\left(0.19-2.13 \mathrm{~g} / \mathrm{m}^{2} / \mathrm{y}\right.$ using an interval accumulation approach and 0.71 
$-1.96 \mathrm{~g} / \mathrm{m}^{2} / \mathrm{y}$ using a linear approach; Table 5) are within the range of those reported for the Rock

399 Creek terraces, which lie in a similar setting and climatic regime. In Table 5, interval accumulation 400 rates of carbonate and accumulation rates using a 'linear approach' (by dividing the carbonate 401 stocks stored in the soils by the corresponding surface age) are presented. The temporal evolution of 402 the inorganic $\mathrm{C}$ abundance in the soils is strongly non-linear (Fig. 9). In soil chronosequences, 403 concentrations or stocks of a component are compared to surface age. The average process rate is 404 often calculated by dividing the measured stocks or concentrations by the soil age (Schlesinger, 405 1990) - a procedure that in many cases does not reproduce the correct values (because a linear trend 406 is implicitly assumed). A time-split approach or the derivation of a regression curve (having in fact 407 an infinite number of time-splits) would be more precise.

408 We calculate only a net accumulation rate of $\mathrm{CaCO}_{3}$. The present-day deposition of dust is probably 409 higher and consists of more than just carbonates, but we assume that part of it is leached from the 410 profiles or removed by wind erosion (Hall, 1999; Applegarth and Dahms, 2001). A two-year record 411 of aeolian influx rates in alpine areas of the Wind River Range yielded values of $2.5-3.3 \mathrm{~g} / \mathrm{m}^{2} / \mathrm{y}$ 412 for mineral dust (Dahms and Rawlins, 1996) and Ferrier et al. (2011) estimated even higher long413 term dust fluxes (c. 3 to $13 \mathrm{~g} / \mathrm{m}^{2} / \mathrm{y}$ ) for the western U.S.

414 Our results suggest that carbonate accumulation, and by extrapolation dust deposition, has varied 415 over major glacial-interglacial cycles. Carbonate stocks of the Popo Agie soils are the lowest in the 416 younger soils and the highest in the older soils, but the stocks do not increase uniformly over time 417 (Table 5). For example, the average $\mathrm{CaCO}_{3}$ accumulation rate during the 260 to 660 ky period was 418 the lowest $\left(0.19 \mathrm{~g} / \mathrm{m}^{2} / \mathrm{y}\right.$; using a linear approach, then the average value between $0-660 \mathrm{ky}$ would 419 be $0.71 \mathrm{~g} / \mathrm{m}^{2} / \mathrm{y}$; Table 5). The accumulation rate increased to $0.79 \mathrm{~g} / \mathrm{m}^{2} / \mathrm{y}$ during the $260-160 \mathrm{kyr}$ 420 interval, then increased again to $2.13 \mathrm{~g} / \mathrm{m}^{2} / \mathrm{y}$ from $160-20 \mathrm{ky}$ (for the period $0-660 \mathrm{ky}$, the linear 421 approach gives $1.96 \mathrm{~g} / \mathrm{m}^{2} / \mathrm{y}$; Table 5), after which the accumulation rate decreased to $0.79 \mathrm{~g} / \mathrm{m}^{2} / \mathrm{y}$ in 422 the post-glacial (Pinedale - Holocene). Independent of the calculation procedure (interval 
accumulation or linear approach), highest rates are related to the period $20-160 \mathrm{ky}$ BP.

424 A moderately comparable pattern of carbonate accumulation is found in the northern Big Horn 425 Basin (Reheis, 1987). The lowest accumulation rate $\left(0.11-1.5 \mathrm{~g} / \mathrm{m}^{2} / \mathrm{y}\right)$ is reported in soils of the 426 oldest terraces $(>400 \mathrm{ky})$ and the highest rates $\left(1.0-5.5 \mathrm{~g} / \mathrm{m}^{2} / \mathrm{y}\right)$ are estimated from the youngest 427 soils. Machette (1985) reported a similar general pattern of $\mathrm{CaCO}_{3}$ accumulation (older = low; 428 younger $=$ high) from New Mexico and Utah.

429 Carbonate stocks in the Popo Agie terrace soils continue to increase with time but do not appear to 430 reach a quasi-steady state before about $1 \mathrm{My}$. Reheis (1990) also observed that arid soils develop at 431 linear rates over several $100 \mathrm{ky}$. In this case soil development reflects progressive dust addition that 432 may be little affected by leaching or erosion. We expect basin soils to accumulate large amounts of $433 \mathrm{Mg}$ and $\mathrm{Ca}$ because the climate is dry enough for these soils to retain much of the carbonate derived 434 from aeolian dust (Reheis, 1990).

\subsection{Chemical weathering pathways}

437 Chemical weathering and leaching of elements are both related to a decreasing value of the open438 system mass transport function $\tau_{j, w}$ (negative values represent losses and positive values gains). As 439 we expected, this is in general not the case for $\mathrm{Ca}$, because it is accumulated during pedogenesis. 440 The higher the carbonate content in the soil is, the higher is the corresponding $\tau_{C a}$ (Fig. 11). 441 However, some weathering and leaching of elements do take place. With increasing soil age the 442 carbonate content and $\tau_{C a}$ increase, but the $\tau_{N a}$ decreases (Fig. 11). Na predominantly derives from 443 plagioclase and our $\tau_{\mathrm{Na}}$ values demonstrate that plagioclase is strongly weathered in the older soils 444 a finding that is also supported by the normalised data of $\mathrm{CaO}$ and $\mathrm{Na}_{2} \mathrm{O}$ to the parent material (Fig. 445 5). In the Wind River Range, plagioclase is transformed over time into kaolinite, illite and smectite 446 (Mavris et al., 2015). With increasing weathering state, also the REE contents (total and oxalate447 extractable content) were mostly higher in the A horizons. Chemical weathering accounts for the 
largest losses of REEs from the parent material (Laveuf and Cornu, 2009). According to Scarciglia

449 et al. $(2009,2011)$, weathering of primary minerals and pedogenetic processes give rise to REE 450 adsorption onto reactive sites of organic matter and clay particles. Clay eluviation and illuviation 451 furthermore contribute to the elemental fractionation (Laveuf and Cornu, 2009; Scarciglia et al., $4522009,2011)$.

453 Under relatively moist conditions, the amounts of pedogenetic, weakly crystalline or amorphous 454 oxyhydroxides increase with time (e.g., Egli et al., 2001; Howard et al., 2012). A similar trend was 455 detected in the wetter, cooler high altitude subalpine-to-alpine environments of the Wind River 456 Range (Dahms et al., 2012). With progressing soil evolution portions of the amorphous forms may 457 be transformed into goethite (FeOOH; cf., Ellis and Atherton, 2003). In sharp contrast, the 458 abundance of pedogenetically formed $\mathrm{Fe}_{\mathrm{ox}}$ (weakly crystalline and amorphous forms) in the Popo 459 Agie terrace soils decreased strongly with increasing time (Fig. 9). Some of the weakly crystalline 460 Fe may also derive from aeolian input - its contribution, however, does not seem to be that high 461 because no clear Fe accumulation with time was detected (Fig. 5). We suggest that, due to the semi462 arid climate, a relatively fast transformation of weakly crystalline and amorphous Fe-forms into 463 crystalline Fe-oxides or -hydroxides (that are not dissolved using oxalate) is likely. This idea is 464 supported by the XRD results: more hematite $\left(\mathrm{Fe}_{2} \mathrm{O}_{3}\right)$ is detected in the older soils (Table 4; Fig. 8) 465 whereas goethite seems to be nearly absent (presumably due to the dry climatic conditions). This 466 weathering relationship is further supported by Quinton et al. (2011) who demonstrated that the 467 absolute and relative hematite abundance in the Little Popo Agie soils (profiles RCT-2-to-5) 468 increased with soil age. Aeolian influx of crystalline Fe-minerals does not seem to be a major 469 process contributing to such a change, because no distinct accumulation (nor depletion) of Fe was 470 detected (Fig. 5).

471 The pedogenetically-formed Fe stocks of the Holocene soil (PB-13-1) corresponds to what has been 472 measured at alpine moraine sites of the Wind River Range (Dahms et al., 2012). At cooler and 
moister sites (montane-to-alpine) the formation of $\mathrm{Fe}_{\mathrm{ox}}$ continues over time, whereas the transformation of weakly- and poorly-crystalline phases into crystalline forms is enhanced at the terrace sites.

Stocks of pedogenic Al-forms in the Popo Agie soils tend to increase with time. This is an expected result of the weathering process; however, the stocks remain at a rather low level even after several $100 \mathrm{ky}\left(200-300 \mathrm{~g} / \mathrm{m}^{2}\right)$ suggesting modest weathering compared to alpine moraine soils of the WRR (Dahms et al., 2012).

Gile et al. (1981) observed that in arid environments the amount of organic carbon generally increases with the clay content. Our observations show that the relation between organic carbon and clay and silt stocks is rather weak (Fig. 12). We see a higher correspondence, however, between nitrogen and silt. We do not really understand why, but we hypothesise that larger amounts of highly-charged phyllosilicates are available in the silt fraction that enable better adsorption of organic matter (having proteinaceous compounds) and protection from microbial decay. The higher amount of highly-charged phyllosilicates could be related to silt-sized mineral grains (e.g., plagioclase, feldspar and micas) that are weathered in situ to clay minerals. Kleber et al. (2007), Kögel-Knabner et al. (2008) and others show the importance of the mineral fraction in OM protection. According to Kleber et al.'s model the formation of particularly strong organo-mineral associations is favoured in the so-called 'contact zone' in situations where proteinaceous materials unfold upon adsorption and thus increase the adhesive strength by adding hydrophobic interactions to electrostatic binding. This could be a reason why such low $\mathrm{C} / \mathrm{N}$ ratios have been measured in our soils. In addition, more aggregates simply may be formed by silt that physically protects organic compounds from decay. Another explanation for the very low $\mathrm{C} / \mathrm{N}$ ratio particularly in the deeper soil horizons, might be due to the exceptionally high accumulation of nitrate beneath the active rooting zone (Graham et al., 2008; Menon et al, 2010). According to these authors, soil resources (water and organic carbon), precipitation, net dryfall and rare leaching events are the primary 
factors that lead to accumulation of $\mathrm{NO}_{3}{ }^{-}-\mathrm{N}$ particularly in this region. Previous measurements of $\mathrm{N}$-deposition in the WRR (Galbraith et al., 1991) showed that a considerable portion of $\mathrm{NO}_{3}{ }^{-} \mathrm{N}$ is imported from upwind sources (presumably) west of the WRR.

\subsection{Climatic inferences}

Reheis (1987) observed that the 'Basin Soils' located farthest from the range front preserve the most complete record of climate change along the Rock Creek chronosequence. The use of alternating clay cutans and $\mathrm{CaCO}_{3}$ layering from thin-section analyses enables Reheis to infer alternations of glacial/interglacial climates in these soils. The inference is that climate fluctuations over time here were enough to cause these changes, but not enough to destroy previously-developed soil characteristics - hence the continuous accumulation of carbonate (regardless of rate) over time. Such features have often a polygenetic origin. Clay increase and cause of clay orientation is often not due to a single genetic process or event (Gunal and Ransom, 2006).

The Popo Agie River soils occur in a similar environment, and so most likely also reflect climate fluctuations over the past c. 700 kyrs. We did not thin-section our soils and so do not have data similar to those of Reheis (1987). Reheis concluded that it is likely that the variable depths of clay and carbonate in the older Rock Creek terraces soils were most likely a result of increases in wetting depth due to an increase in available water capacity (AWC) coincident with the addition of aeolian fines over time rather than to changes in overall climate variability (e.g., higher precipitation levels during interglacial periods). Overall, the Rock Creek soils data suggest an overall pattern of less precipitation during glacial periods. Alternately, Nettleton and Chadwick (1991) suggested that moisture conditions during the Pleistocene in the lower Wind River Basin near Riverton were not appreciably different from those at present and also suggest that dust deposition rates have not appreciably changed. 
Our $\mathrm{CaCO}_{3}$ accumulation data are similar to those for Rock Creek and it seems reasonable that

523 some carbonates in the soils would be dissolved during periods of greater moisture. However, our results suggest that $\mathrm{CaCO}_{3}$ accumulates most effectively in the soils of the western Wind River Basin during the cool, windy glacial periods rather than during warmer, less windy interglacials (Table 5). Hall and Jaworowski (1999) have suggested that A horizons of Bull Lake-age are thinner and $\mathrm{Bt}$ horizons are closer to the surface than on soils of nearby Pinedale moraines due to erosion caused by the cold foehn winds off the local valley glaciers. Studies of Greenland and the Antarctic ice cores show that MIS glacial stages are drier and windier (and thus dustier) than interglacials (e.g., Fuhrer et al., 1999; Svensson et al., 2000). Thus, it seems reasonable to assume that more Carich materials normally are in flux in a glaciated region during time periods that are predominately 532 glacial than during warmer periods. It appears that, on average, our soil $\mathrm{CaCO}_{3}$ accumulation rates 533 (and associated aeolian deposition rates) were the highest during MIS 6-2 (c. $160 \mathrm{ky}$; Cohen and 534 Gibbard, 2011). Note that the time-span 160-to-20 ky predominantly covers cold MIS phases. The 535 other time-split periods (660-to-260 ky and 260-to-160 ky) include a comparatively larger 536 proportion of warm (interglacial) phases. Machette's (1985) model for long-term carbonate 537 accumulation shows that soils in locations with climatic regimes similar to that of the Popo Agie 538 (Buena Vista \& Boulder/Denver, Colorado) fall into the 'influx limited' region of the model 539 (Machette, 1985). This model suggests that the variations observed in the Rock Creek, Wind River, 540 and Popo Agie soils are more likely to be caused by variations in aeolian influx under the influence 541 of climate variability than either influx rates or glacial/interglacial climate variations acting alone.

542 This reasoning should include a decrease in vegetation cover during glacial periods. We suggest 543 that change in rates of soil carbonate accumulation does not exclusively indicate a climate signal 544 but probably is overprinted by limits to the supply of sediments, the availability of aeolian material, 545 balanced by the effect(s) of increasing loss by erosion of fines as the surfaces age and the 546 decreasing ability of the surface soil to accumulate more eolian fines as pore spaces fill with 
547 infiltrated silt and clay. These factors may well influence the (apparently) decreasing accumulation 548 rates detected in the older soils.

\section{Conclusions}

552 Chronosequences are a fundamental tool for studying and representing change in Earth surface 553 systems. Increasingly, chronosequences are understood to be much more complex than a simple 554 monotonic progression from a starting point to a stable end-state (Phillips, 2015). In this case, the soil physical and chemical characteristics combined with the presumed age associations allow us to derive interval accumulation rates of $\mathrm{CaCO}_{3}$ that appear to show varying rates of dust deposition over several glacial-interglacial cycles The development trajectories thus show a certain sensitivity 558 to disturbances and changes (Phillips, 2015).

559 The well-preserved terraces along the Popo Agie River of the southeastern Wind River Range 560 allows us to develop a relative-age chronosequence for soil development on (mostly) granitic 561 alluvium and to compare soil development here with soils on similar terrace sequences elsewhere in 562 the western U.S. Carbonate stocks in the fine earth of the soils increase with increasing soil age and 563 are thought to be related to aeolian influx over time and influenced by the major cycles of mid-to564 late Pleistocene climate change represented in our chronosequence [Holocene, Pinedale (20 ky), 565 early and late Bull lake (160 and $260 \mathrm{ky}$ ) and Sacagawea Ridge (c. $660 \mathrm{ky}$ )]. By inference of the 566 carbonate stocks, aeolian influx of inorganic carbon apparently was lowest in this area during the 567 period of c. $260-660 \mathrm{ky}$ and the highest during the period of c. $160-20 \mathrm{ky}$.

568 A quasi-steady state situation (where inputs of materials to the soil system and outputs via erosion 569 and weathering are almost equal) does not appear to have been reached by $660 \mathrm{ky}$. The change in 
571 also related to a supply limitation of sediments, the subsequent disposability of aeolian material, 572 and increasing erosion of older soil surfaces.

573 We suggest a scenario where the long-term carbonate accumulation rates in soils of Quaternary 574 glacial, alluvial, and glacio-fluvial sequences of this region are controlled through the rates of 575 aeolian influx over time as modified by glacial/interglacial climate variations rather than by 576 glacial/interglacial variations in moisture availability. Thus we consider the carbonate accumulation 577 rates in these soils to be 'influx limited' rather than 'moisture limited' (Machette, 1985) so that the 578 soil-forming regime of these soils is more closely related to that of the semi-arid Rocky Mountain579 Intermountain region than to the arid southwest of New Mexico, Arizona, and southern Nevada and 580 California.

581 Compared to other published results, the carbonate accumulation rates determined for the Wind 582 River Range terraces were relatively low. Despite the dominance of carbonate accumulation as a 583 pedogenetic process, chemical weathering and leaching of primary minerals occurred (e.g. 584 plagioclase weathering coupled with a subsequent $\mathrm{Na}$ release). In addition, pedogenetic $\mathrm{Al}$ and $\mathrm{Mn}$ 585 have formed, but at relatively low rates when compared to moister and cooler conditions in the 586 Wind River Range. Due to the dry climate, weakly crystalline and amorphous Fe-forms seemed to 587 be transformed relatively quickly into crystalline forms (hematite). With increasing age, inorganic 588 carbon (with an average at the oldest sites of $60 \mathrm{~kg} \mathrm{C}$ inorg $/ \mathrm{m}^{2}$ ) becomes the lion's share of the stored 589 total carbon. Organic carbon remained relatively at a stable level (about $8-10 \mathrm{~kg} \mathrm{C}$ org $/ \mathrm{m}^{2}$ ) over the 590 entire soil formation phase.

\section{Acknowledgements}

594 We would like to thank S. Röthlisberger and M. Kovacic for their help in the laboratory at the 595 University of Zürich. Students in the Environmental Sediment Analysis class (Geog4220) at the 
University of Northern Iowa helped Dahms to develop the data for $\% \mathrm{CaCO}_{3}$. We are, furthermore, indebted to Marith C. Reheis and an unknown reviewer for their helpful comments on an earlier version of the manuscript.

References

602 Anders, M.H., Saltzman, J., Hemming, S.R., 2009. Neogene tephra correlations in eastern Idaho 603 and Wyoming: Implications for yellowstone hotspot-related volcanism and tectonic activity. Geol. Soc. Am. Bull. 121, 827-856.

Applegarth, M.T., Dahms, D.E., 2001. Soil catenas of calcareous tills, Whiskey Basin, Wyoming, USA. Catena 42, 17-38.

Applegarth, M.T., Dahms, D.E. 2004. Aeolian modification of moraine soils, Whiskey Basin, Wyoming, USA. Earth Surf. Proc. Land. 29, 579-585.

Bierman, P.R., Montgomery, D.R., 2014. Key Concepts in Geomorphology. W.H. Freeman, NY.

Birkeland, P.W., 1973. Use of Relative Age-Dating Methods in a Stratigraphic Study of Rock Glacier Deposits, Mt. Sopris, Colorado. Arct. Alp. Res. 5, 401-41.

Birkeland, P.W., Burke, R.M., Shroba, R.R., 1987. Holocene Alpine Soils in Gneissic Cirque Deposits, Colorado Front Range. U.S. Geol. Surv. Bull. 1590-E.

Birkeland, P. W., Machette, M., Haller, K., 1991. Soils as tool for applied Quaternary geology.

$$
\text { Miscellaneous Publication 91-3, Utah Geological and Mineral Survey. }
$$

Blackwelder, E., 1915. Post-Cretaceous history of the mountains of western Wyoming. J. Geol. 23, $302-340$

Boulding, B.H., Boulding, J.R., 1981. Genesis of Silty and Clayey Material in Some Alpine Soils in 619 the Teton Mountains, Wyoming and Idaho. Indiana Acad. Sci. Proc. 91, 552-562. 
620 Chadwick, O.A., Brimhall, G.H., Hendricks, D.M., 1990. From a black to a grey box - A mass 621 balance interpretation of pedogenesis. Geomorphology 3, 369-390.

622 Chadwick, O.A., Hall, R.D., Phillips, F.M., 1997. Chronology of Pleistocene glacial advances in the 623 central Rocky Mountains. Geol. Soc. Am. Null. 109, 1443-1452.

624 Cohen, K.M., Gibbard, P., 2011. Global chronostratigraphical correlation table for the last 2.7 625 million years. Subcommission on Quaternary Stratigraphy (International Commission on 626 Stratigraphy), Cambridge, England.

627 Colman, S.M., Pierce, K.L., 1986. The glacial sequence near McCall, Idaho--weathering rinds, soil 628 development, morphology, and other relative-age criteria. Quat. Res. 25, 25-42.

629 Dahms, D.E., 1993. Mineralogical evidence for eolian contribution to soils of late Quaternary 630 moraines, Wind River Mountains, Wyoming, USA. Geoderma 59, 175-196.

631 Dahms, D.E., 2002. Glacial Stratigraphy of Stough Creek Basin, Wind River Range, Wyoming. 632 Geomorphology 42, 59-83.

633 Dahms, D.E, 2010. Soils and glacial stratigraphy of the Popo Agie River Basin, southern Wind 634 River Range, Wyoming. Abstracts with Programs, \#180207 (Paper No. 95-4), Geological 635 Society of America Annual Meeting, 31 Oct-3 Nov, Denver, CO.

636 Dahms, D.E., 2004a. Glacial limits in the middle and southern rocky Mountains, USA, south of the 637 Yellowstone Ice Cap. In: Ehlers, J., Gibbard, P.L. (Eds.), Quaternary Glaciations - Extent \& 638 Chronology, Part II: North America. Developments in Quaternary Science, Vol 2b. Elsevier, 639 Amsterdam, pp. 269-282.

640 Dahms, D.E., 2004b. Relative and numeric age data for Pleistocene glacial deposits and diamictons 641 in and near Sinks Canyon, Wind River Range, Wyoming, U.S.A. Arct. Antarct. Alp. Res. 36, 59$642 \quad 77$.

643 Dahms, D.E., Rawlins, C.L., 1996. A two-year record of eolian sedimentation in the Wind River 644 Range, Wyoming, U.S.A. Arct. Alp. Res. 28, 210-216. 
645 Dahms, D. Favilli, F., Krebs, R., Egli, M., 2012. Soil weathering and accumulation rates of oxalate646 extractable phases from alpine chronosequences of up to 1 Ma in age. Geomorphology 151-152, $64799-113$.

648 Dixon, J., 1992. Alpine and Subalpine Soil Properties as Paleoenvironmental Indicators. Phys. $649 \quad$ Geog. 12, 370-384.

650 Egli, M., Fitze, P. Mirabella, A., 2001. Weathering and evolution of soils formed on granitic, 651 glacial deposits: results from chronosequences of Swiss alpine environments. Catena, 45, 19-47. 652 Ellis, S., Atherton, J.K., 2003. Properties and development of soils on reclaimed alluvial sediments 653 of the Humber estuary, eastern England. Catena 52, 129-147.

654 Fabel, D., Harbor, J., Dahms, D., James, A., Elmore, D., Horn, L., Daley, K., Steele, C., 2004. Spa655 tial patterns of glacial Erosion at a valley scale derived from terrestrial cosmogenic ${ }^{10} \mathrm{Be}$ and ${ }^{26} \mathrm{Al}$ 656 concentrations in rock. Ann. Assoc. Am. Geogr. 94, 241-255.

657 Ferrier, K.L., Kirchner, J.W., Finkel, R.C., 2011. Estimating millennial-scale rates of dust 658 incorporation into eroding hillslopes regolith using cosmogenic nuclides and immobile 659 weathering tracers. J. Geophys. Res. 116, F03022.

660 Fuhrer, K., Wolf, E.W., Johnsen, S.J., 1999. Timescales for dust variability in the Greenland Ice 661 Core Project (GRIP) ice core in the last 100,000 years. J. Geophys. Res. - Atmos. 104 (D24), $662 \quad 31043-31052$.

663 Galbraith, A.F., Harrelson, C.C., and Rawlins, C., 1991. Acid deposition in the Wind River 664 Mountains. Air Quality Related Values Report 2, Bridger-Teton National Forest, Jackson, $665 \quad$ Wyoming, 48p.

666 Gile, L.H., Peterson, F.F., Grossman, R.B., 1966. Morphological and genetic sequences of 667 carbonate accumulation in desert soils. Soil Sci. 101, 347-360. 
Gile, L.H., Hawley, J.W., Grossman, R.B., 1981. Soils and geomorphology in the Basin and Range area of Southern New Mexico - Guidebook to the Desert Project. New Mexico Bureau of Mines \& Mineral Resources, Memoir 39, University of New Mexico Printing Plant, Socorro.

Gosse, J.C., Evenson, E.B., Klein, J., Sorenson, C., 2003. Cosmogenic nuclide glacial geochronology in the Wind River Range, Wyoming. In: Easterbrook, D.J. (Ed.), Quaternary Geology of the United States. INQUA 2003 Field Guide Volume, 2003 INQUA Congress. Desert Research Institute, Reno, Nv, pp. 49-56.

Graham, R.C., Hirmas, D.R., Wood, Y.A., Amrhein, C., 2008. Large near-surface nitrate pools in soils capped by desert pavement in the Mojave Desert, California. Geology 36, 259-262.

Gunal, H, Ransom, M.D., 2006. Clay illuviation and calcium carbonate accumulation along a precipitation gradient in Kansas. Catena 69, 59-69

Hall, R.D., 1999. Effects of Climate Change on Soils in Glacial Deposits, Wind River Range, Wyoming. Quat. Res. 51, 248-261.

Hall, R.D., Shroba, R.R., 1995. Soil evidence for a glaciation intermediate between the Bull Lake and Pinedale glaciations at Fremont Lake, Wind River Range, Wyoming. Arct. Alp. Res. 27, 8998.

Hall, R.D., Jaworowski, C., 1999. Reinterpretation of the Cedar Ridge section, Wind River Range, Wyoming: Implications for the glacial chronology of the Rocky Mountains. Geological Society of America Bulletin 111, 1233-1249.

Hancock, G. S., R.S. Anderson, O.A. Chadwick and R.C. Finkel, 1999. Dating fluvial terraces with ${ }^{10} \mathrm{Be}$ and ${ }^{26} \mathrm{Al}$ profiles: application to the Wind river, Wyoming. Geomorphology 27, 41-60.

Hitz, C., Egli, M., Fitze, P., 2002. Determination of the sampling volume for representative analysis of alpine soils. Z. Pflanz. Bodenkunde 165, 326-331.

Howard, J.L., Clawson, C.R., Daniels, W.L., 2012. A comparison of mineralogical techniques and potassium adsorption isotherm analysis for relative dating and correlation of Late Quaternary 
soil chronosequences. Geoderma 179-180, 81-95.

694 Hutton, J. T., 1977. Titanium and zirconium minerals. In: Dixon, J. B., Weed, S. B. (Eds.), Minerals 695 in Soil Environments. Madison, Wisconsin, Soil Science Society of America, pp. 673-688.

696 Jackson, M. L., 1969. Soil Chemical Analysis: Advanced Course. Department of Soil Science, 697 University of Wisconsin, Madison.

698 Jaworowski, C., 1992. A probable new Lava Creek ash locality: implication for Quaternary 699 geologic studies in the western Wind River Basin, Wyoming, USA. Contributions to Geology, $700 \quad$ University of Wyoming 29, 111-117.

701 Kleber, M., Sollins, P., Sutton, R., 2007. A conceptual model of organo-mineral interactions in 702 soils: self-assembly of organic molecular fragments into zonal structures on mineral surfaces. 703 Biogeochemistry 85, 9-24.

704 Klute, A., 1986. Methods of Soil Analysis: Part 1, Physical and Mineralogical Methods, $2^{\text {nd }}$ ed. 705 Madison, WI: American Society of Agronomy.

706 Kögel-Knabner, I., Guggenberger, G., Kleber, M., Kandeler, E., Kalbitz, K., Scheu, S., Eusterhues, 707 K., Leinweber, P., 2008. Organo-mineral associations in temperate soils: Integrating biology, 708 mineralogy, and organic matter chemistry. J. Plant Nutr. Soil Sc. 171, 61-82.

709 Landi, A., Mermut, A.R., Anderson, D.W., 2003. Origin and rate of pedogenic carbonate 710 accumulation in Saskatchewan soils, Canada. Geoderma 117, 143-156.

711 Laveuf, C., Cornu, S., 2009. A review on the potentiality of Rare Earth Elements to trace 712 pedogenetic processes. Geoderma 154, 1-12.

713 Litaor, M., 1987. The Influence of Eolian Dust on the Genesis of Alpine Soils in the Front Range, 714 Colorado. Soil Sci. Soc. Am. Jour. 51, 142-147.

715 Litaor, M., 1988. Reply to Comments on 'The Influence of Eolian Dust on Alpine Soils.' Soil Sci. $716 \quad$ Soc. Am. J. 52, 301-302. 
717 Machette, M.N., 1985. Calcic soils of the southwestern United States. In: Weide, D.L. (Ed.), Soils 718 and Quaternary Geology of the Southwestern United States. Geological Society of America 719 Special Paper 203, pp. 1-21.

720 Marchand, D.E., 1970. Soil Contamination in the White Mountains, eastern California. Geol. Soc. $721 \quad$ Am. Bull. 81, 2497-2506.

722 Massatti, R.T., 2007. A floristic inventory of the east slope of the Wind River Mountain Range and 723 vicinity, Wyoming. PhD Thesis, University of Wyoming, ProQuest, UMI Dissertations 724 Publishing.

725 Mavris, C., G. Furrer, D. Dahms, S.P. Anderson, A. Blum, J. Goetze, A. Wells, M. Egli, 2015. 726 Decoding potential effects of climate and vegetation change on mineral weathering in alpine 727 soils: An experimental study in the Wind River Range (Wyoming, USA). Geoderma 255-256, $728 \quad 12-26$.

729 McFadden, L.D., 2013. Strongly dust-influenced soils and what they tell us about landscape 730 dynamics in vegetated aridlands of the southwestern United States. Spec Pap Geol Soc America $731500,501-532$.

732 McKeague, J.A., Brydon, J.E., Miles, N.M., 1971. Differentiation of forms of extractable iron and 733 aluminium in soils. Soil Sci Soc Am Proc 35, 33-38.

734 Mears, B., 1974. The evolution of the Rocky Mountain glacial model. In: Coates, D.R. (Ed.), 735 Glacial Geomorphology. SUNY-Binghamton, NY, pp. 11-40.

736 Menon, M., Parratt, R.T., Kropf, C.A., Tyler, S.W., 2010. Factors contributing to nitrate 737 accumulation in mesic desert vadose zones in Spanish Springs Valley, Nevada (USA). J Arid $738 \quad$ Environ 74, 1033-1040.

739 Mizota, C., van Reeuwijk, L.P., 1989. Clay mineralogy and chemistry of soils formed in volcanic 740 material in diverse climate regions. International Soil Reference and Information Centre, Soil 741 Monograph, vol. 2. Wageningen. 
Mourier, B., Poulenard, J., Chauvel, C., Faivre, P., Carcaillet, C., 2008. Distinguishing subalpine soil types using extractible Al and Fe fractions and REE geochemistry. Geoderma 145, 107-120.

744 Muhs, D.R., 2013. The geologic records of dust in the Quaternary. Aeolian Research 9, 3-48.

745 Muhs, D.R., Benedict, J.B., 2006. Eolian additions to late Quaternary alpine soils, Indian Peaks 746 Wilderness Area, Colorado Front Range. Arct. Antarct. Alp. Res. 38, 120-130.

747 Muhs, D.R., Bush, E.A., Stewart, K.D., Rowland, T.R., Crittenden, R.E., 1990. Geochemical 748 evidence of Saharan dust parent material for soils developed on Quaternary limestones of 749 Caribbean and western Atlantic islands. Quat. Res. 33, 157-177.

750 Muhs, D.R., Benedict, J.B. and Evans, J., 1992. Sources of Probable Eolian Sediments on Late 751 Quaternary Alpine Moraines, Colorado Front Range: Evidence from Trace Element 752 Geochemistry. Abstracts of the $12^{\text {th }}$ Biennial Mtg., AMQUA, Davis, Calif., August 24-26.

753 Muhs, D.R., Prins, M.A., Machalett, B., 2014. Loess as Quaternary paleoenvironmental indicator. $754 \quad$ PAGES Magazine 22, 84-85.

755 Nettleton, W.D., Chadwick, O.A., 1991. Soil-landscape relationships in the Wind River Basin, 756 Wyoming. The Mountain Geologist 28, 3-11.

757 Phillips, F.M., Zreda, M., Gosse, J., Klein, J., Evenson, E., Hall, R.D., Chadwick, O.A., Sharma, P., 758 1997. Cosmogenic ${ }^{36} \mathrm{Cl}$ and ${ }^{10} \mathrm{Be}$ ages of Quaternary glacial and fluvial deposits of the Wind 759 River Range, Wyoming. Geol. Soc. Am. Bull. 109, 1453-1463.

760 Phillips, D.J., 2015. The robustness of chronosequences. Ecol. Model. 298, 16-23.

761 Picard, M.D., 1993. The early Mesozoic history of Wyoming. In: Snoke, A.W., Steidtmann, J.R., 762 Roberts, S.M. (Eds.), Geology of Wyoming, Geological Survey of Wyoming Memoir \#5, pp. $763 \quad 210-248$.

764 Pierce, K.L., 2004. Pleistocene glaciations in the Rocky Mountains. In: Gillespie, A.R., Porter, 765 S.C., Atwater, B.F. (Eds.), The Quaternary Period in the United States. Developments in 766 Quaternary Science 1, Jim Rose (Series Ed.). Elsevier, Amsterdam, pp. 63-76. 
PRISM Climate Group, 2014. Annual average precipitation (1981-2010). Oregon State University.

768 Quinton, E.E., Dahms, D.E., Geiss, C.E., 2011. Magnetic analyses of soils from the Wind River 769 Range, Wyoming, constrain rates and pathways of magnetic enhancement for soils from semiarid climates. Geochem. Geophys. Geosyst. 12, Q07Z30.

Reheis, M.C., 1987. Soils in granitic alluvium in humid and semiarid climates along Rock Creek, Carbon County, Montana: U.S. Geological Survey Bulletin 1590-D.

Reheis, M.C., 1988. Replacement of silicate grains by $\mathrm{CaCO}_{3}$ in semiarid soils of south-central Montana, U.S.A. Geoderma 41, 243-261.

Reheis, M.C., 1990. Influence of climate and eolian dust on the major-element chemistry and clay mineralogy of soils in the northern Bighorn Basin, U.S.A. Catena 17, 219-248.

Reheis, M. C., Kihl, R., 1995. Dust deposition in southern Nevada and California, 1984-1989: Relations to climate, source area, and source lithology. J. Geophys. Res. 100 (D5), 8893-8918.

Reheis, M.C., Sowers, J.M., Taylor, E.M., McFadden, L.D., Harden, J.W., 1992. Morphology and genesis of carbonate soils on the Kyle Canyon fan, Nevada, U.S.A. Geoderma 52, 303-342.

Richmond, G.M., 1948. Modification of Blackwelder's sequence of Pleistocene glaciation in the Wind River Mountains, Wyoming. Geol. Soc. Am. Bull. 59, 1400-1401.

Richmond, G.M., 1964. Three pre-Bull Lake tills in the Wind River Mountains, Wyoming: A reinterpretation. U.S. Geol. Surv. Prof. Paper 501-D, 104-109.

Richmond, G.M., 1973. Geologic Map of the Fremont Lake South quadrangle, Sublette County, Wyoming. U.S. Geological survey, Geologic Quadrangle Map GQ-1138.

Richmond, G.M., 1986. Stratigraphy and correlation of glacial deposits of the Rocky Mountains, the Coorado Plateau \& the ranges of the Great Basin. Quat. Sci. Rev. 5, 99-127.

Richmond, G.M., 1987. Type Pinedale Till in the Fremont Lake area, Wind River Range, 791 Wyoming. Geological Society of America Centennial Field Guide - Rocky Mountain Section, pp. 201-204. 
Sauer, D., Schellmann, G., Stahr, K., 2007. A soil chronosequence in the semi-arid environment of Patagonia (Argentina). Catena 71, 382-393.

Scarciglia, F., Barca, D., De Rosa, R., Pulice I., 2009. Application of laser ablation ICP-MS and traditional micromorphological techniques to the study of an Alfisol (Sardinia, Italy) in thin sections: Insights into trace element distribution. Geoderma 152, 113-126.

Scarciglia, F., Tuccimei, P., Vacca, A., Barca, D., Pulice, I., Salzano, R., Soligo, M., 2011. Soil genesis, morphodynamic processes and chronological implications in two soil transects of SE Sardinia, Italy: Traditional pedological study coupled with laser ablation ICP-MS and radionuclide analyses. Geoderma 162, 39-64.

Schlesinger, W. H., 1990. Evidence from chronosequence studies for a low carbon-storage potential of soils. Nature 348, 232-234.

Shroba, R.R., Birkeland, P.W., 1983. Trends in Late Quaternary Soil Development in the Rocky Mountains and Sierra Nevada of the western United States. In: Wright, H.E. (Editor), Late Quaternary Environments of the United States, Volume I. The Late Pleistocene. Univ. of Minn., Minneapolis, pp.145-156.

Singer, M. J., Janitzky, P., 1986. Field and laboratory procedures used in a soil chronosequence study. U.S. Geological Survey Bulletin, 1648.

Soil Survey Division Staff. 1993. Soil survey manual. Soil Conservation Service. U.S. Department of Agriculture Handbook 18.

Soil Survey Staff, 2014. Keys to Soil Taxonomy, 12th ed. USDA-Natural Resources Conservation Service, Washington, DC.

Sorenson, C.J., 1987. Soils Map of the Fremont Lake South Quadrangle, Sublette County, Wyoming. U.S. Geol. Surv., Misc. Invest. Map I-1800.

Sun, S.S., McDonough, W.F., 1989. Chemical and isotopic systematics of oceanic basalts: implications for mantle composition and processes. In: Saunder, A.D., Norry, M.J. (Eds.), 
817 Magmatism in Oceanic Basins. Geological Society of London, Special Publication 42, London, $818 \quad$ pp. $313-345$.

819 Svensson, A., Biscaye, P.E., Grousset, F.E., 2000. Characterization of late glacial continental dust 820 in the Greenland Ice Core Project ice core. J. Geophy. Res. 105 (D4), 4637-4656.

821 Swanson, D.K., 1985. Soil Catenas on Pinedale and Bull Lake Moraines, Willow Lake, Wind River 822 Mountains, Wyoming. Catena 12, 329-342.

823 Taylor, S.R., McLennan, S.M., 1985. The Continental Crust: Its Composition and Evolution. $824 \quad$ Blackwell, Oxford.

825 Thorn, C.E., Darmody, R.G., 1980. Contemporary Eolian Sediments in the Alpine Zone, Colorado $826 \quad$ Front Range. Phys. Geog. 1, 162-171.

827 US Climate Data, 2015 (online). http://www.usclimatedata.com/climate/lander/wyoming/united$828 \quad$ states/uswy0101

829 Vandenberghe, J., 2015. River terraces as a response to climatic forcing: Formation processes, 830 sedimentary characteristics and sites for human occupation. Quatern. Int. 370, 3-11.

831 Williams, J., 1973. Neoglacial Chronology of the 4th of July Cirque, Central Colorado Front 832 Range: Discussion. Geol. Soc. Am. Bull. 84, 3761-3765. 


\section{Figure captions}

Fig. 1. Location of the Popo Agie Basin on the southeastern flank of the Wind River Range in west-central Wyoming. Note the three forks of the Popo Agie grade to the Wind River south of Riverton in the central Wind River Basin and that the Wind River becomes the Big Horn River at the northern mouth of Wind River Canyon (located just north of the lake at the midupper right of the image (Google Earth Pro).

Fig. 2. Location of the studied terrace elements and associated soil profiles along each of the three forks of the Popo Agie River: A) the North Fork, B) the Middle Fork (together with the airport terrace AT (Jaworowski, 1992); see text), C) the Little Popo Agie (Red Canyon), D) terraces of RCT2-5 in Little Popo Agie and E) view toward the north from RCT-4 (Little Popo Agie). Photos generally are SE-to-NW (for A) to C)). The terrace/soil locations are within 2.3 miles of the mouth of North Fork Canyon, 5.0 miles from the mouth of Sinks Canyon (Middle Popo Agie) and within 0.5 mile of the mouth of Little Popo Agie Canyon.

Fig. 3. Investigated soil profiles with designated horizons. For RCT5, the inset shows the character of the Bkm (cemented 'petrocalcic') horizon of the U.S. Soil Taxonomy.

Fig. 4. A) Average concentration of inorganic and B) total carbon as a function of soil depth and age. Values are averages of the soils within the corresponding age classes.

Fig. 5. Spider diagram of normalised (to the parent material $=\mathrm{PM}$ ) A) major elements in the A horizon, B) trace elements in the A horizon, C) major elements in the $\mathrm{B}(\mathrm{k})$ horizon and $\mathrm{D})$ trace elements in the $\mathrm{B}(\mathrm{k})$ horizon. The concentrations are given as a function of surface age. 
To account for the dilution effect of $\mathrm{CaCO}_{3}$, the contents were ratioed to the immobile element $\mathrm{Zr}$ :

Conc. measured(norm)/Conc. PM (norm) $=\frac{\frac{C_{s}}{Z r_{s}}}{{ }_{\frac{C_{P M}}{Z r_{P M}}}}$ where $\mathrm{C}_{\mathrm{s}}=$ element concentration of the sample, $\mathrm{Zr}_{\mathrm{s}}=\mathrm{Zr}$ concentration of the sample, $\mathrm{C}_{\mathrm{PM}}=$ element concentration of $\mathrm{PM}$ (parent material) and $\mathrm{Zr}_{\mathrm{PM}}=\mathrm{Zr}$ concentration of $\mathrm{PM}$.

Fig. 6. Normalised (to the parent material $=$ PM) REE concentrations for some selected profiles as a function of terrace age. The total content and the oxalate-extractable fraction of selected REEs are shown for A) the A-horizon and B) the B(k)-horizon. The content of Sm in the A horizon was below the XRF detection limit.

Fig. 7. Binary diagram of concentration ratios of $\mathrm{A}$ ) $\mathrm{Ti} / \mathrm{Zr}$ vs $\mathrm{Ti} / \mathrm{Nb}$ and $\mathrm{B}$ ) $\mathrm{Ti} / \mathrm{Zr}$ vs $\mathrm{Ce} / \mathrm{Y}$ for samples of the topsoil, the horizons with carbonate accumulation (Bk, $\mathrm{CBk}, \mathrm{Ck})$ and the $\mathrm{C}$ horizon from the various sites.

Fig. 8. X-ray diffraction pattern for three samples from the soils PB-13-2 (Bw horizon), GR13-1 (Btk) and PB-13-1 (AB horizon) having different ages. The diffraction peaks associated with quartz $(\mathrm{Q})$, calcite $(\mathrm{Cc})$ and hematite $(\mathrm{H})$ are labelled.

Fig. 9. A) Inorganic and B) organic carbon stocks (average \pm standard deviation) as a function of age ( \pm estimated error range).

Fig. 10. Average ( \pm SD) accumulation (abundance) of pedogenetically formed A) Fe, B) Al and C) $\mathrm{Mn}$ in the entire profiles as a function of terrace age ( \pm error range). 
Fig. 11. A) Comparison of the relative losses or gains (open system mass transport function $\tau$ ) of $\mathrm{Ca}$ with the carbonate content and $\mathrm{B}$ ) relative mass changes of $\mathrm{Ca}$ vs. $\mathrm{Na}$.

Fig. 12. Comparison of organic C stocks with the abundance of A) clay and B) silt of the individual soil horizons. Significant correlations only exist between C) N stocks and clay abundance and D) $\mathrm{N}$ and silt abundance. 
Click here to download high resolution image

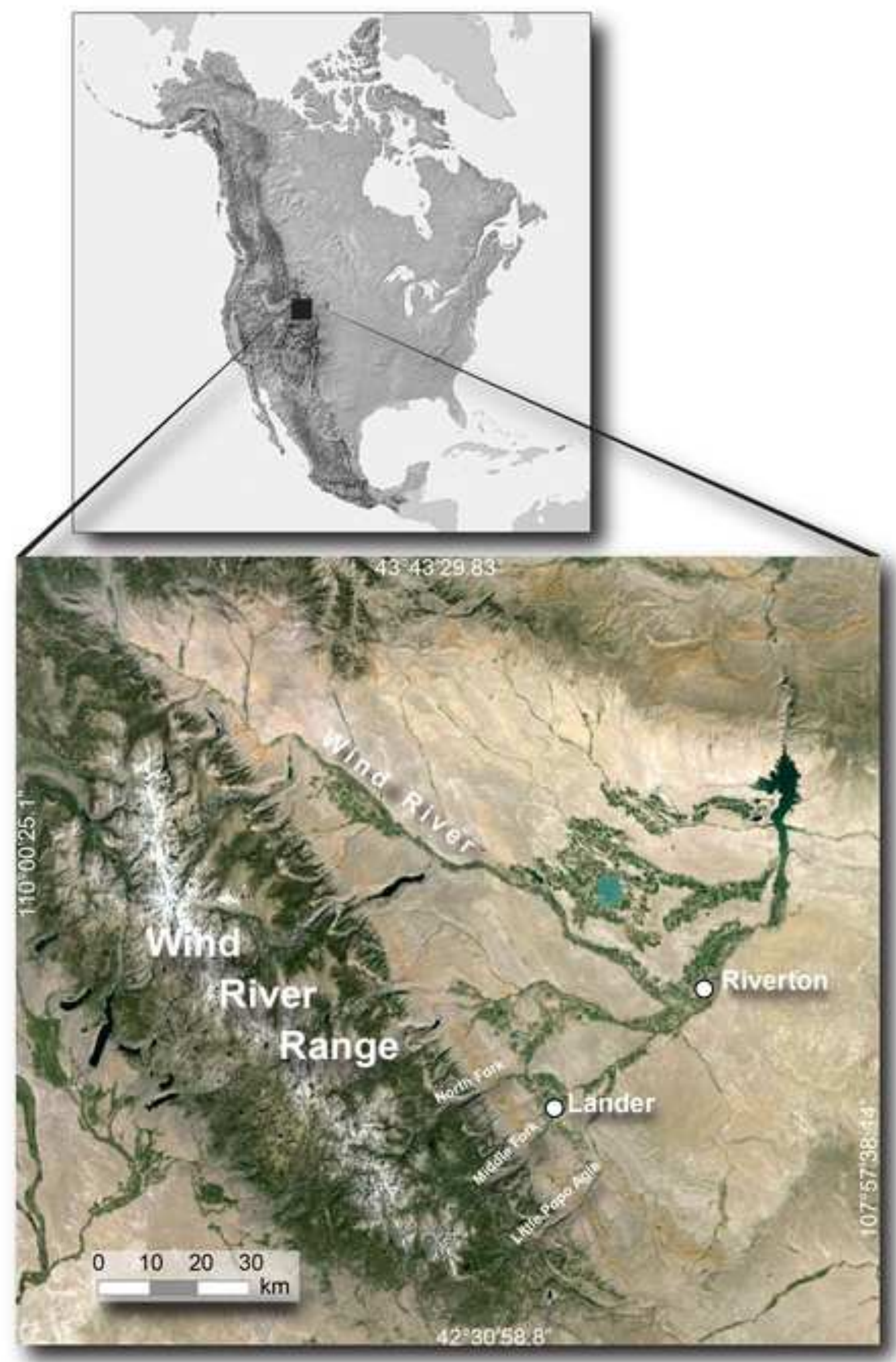


Click here to download high resolution image
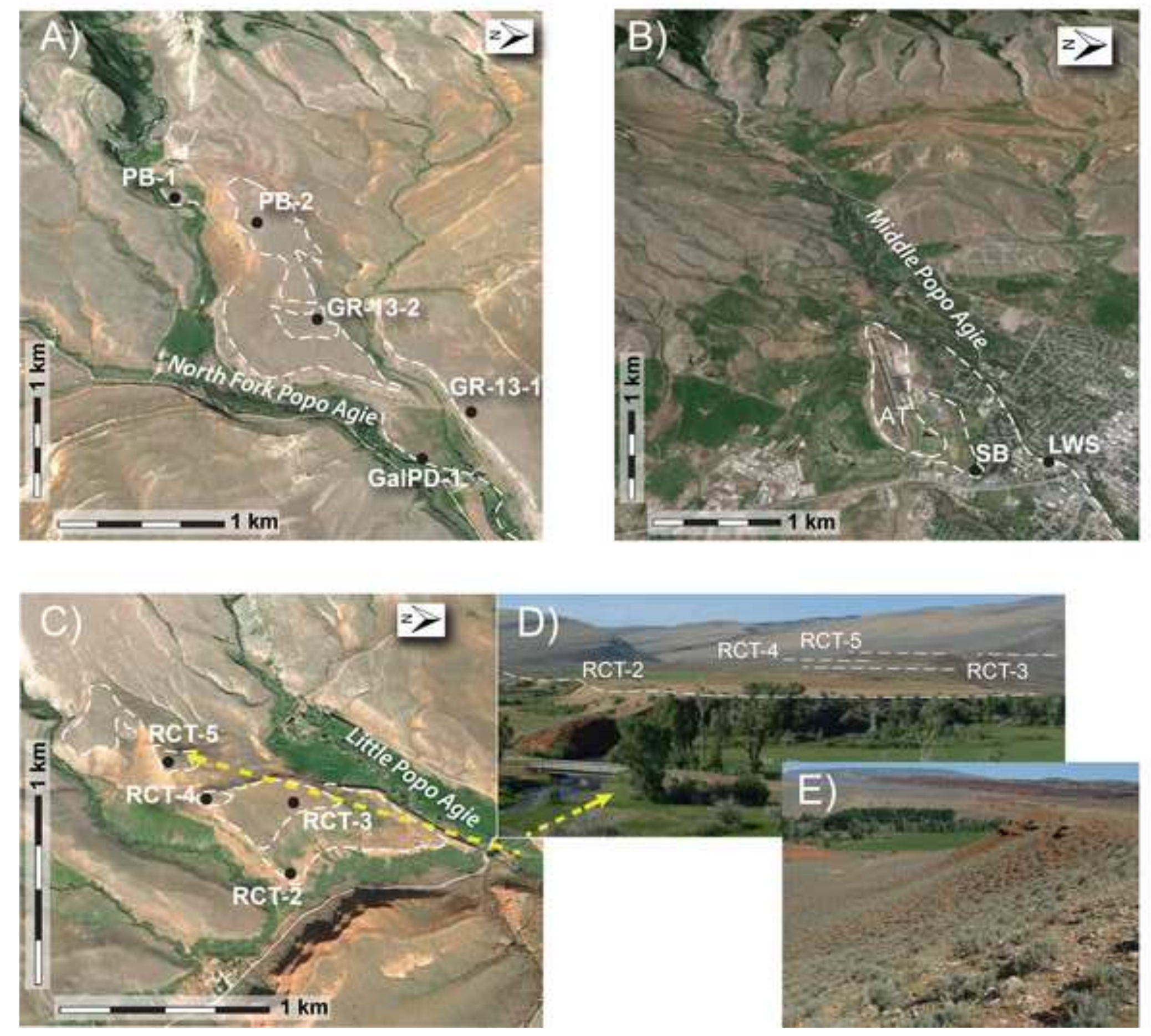
Click here to download high resolution image

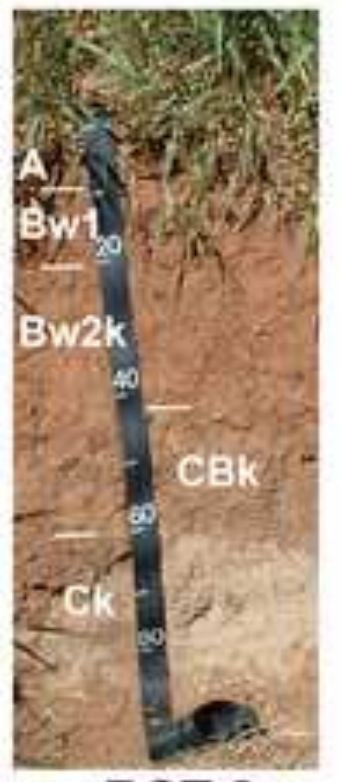

RCT-2

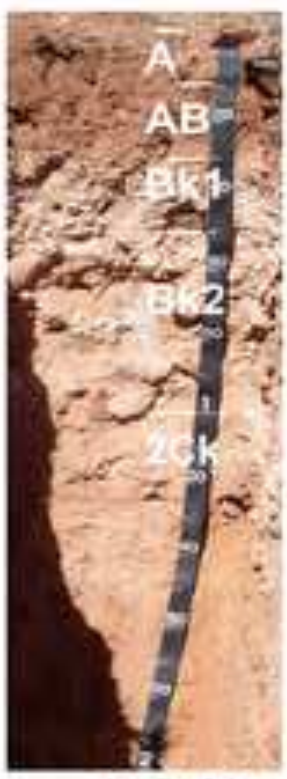

RCT-3

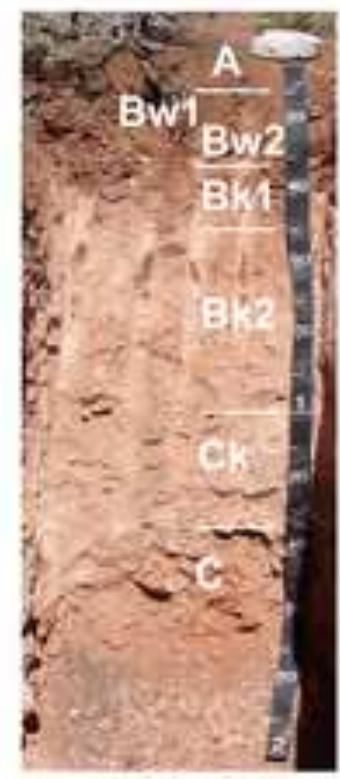

RCT-4

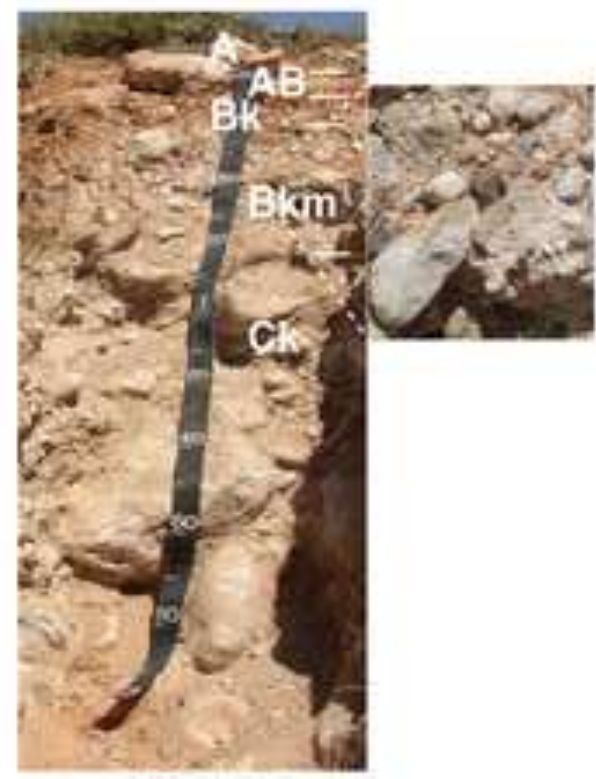

RCT-5

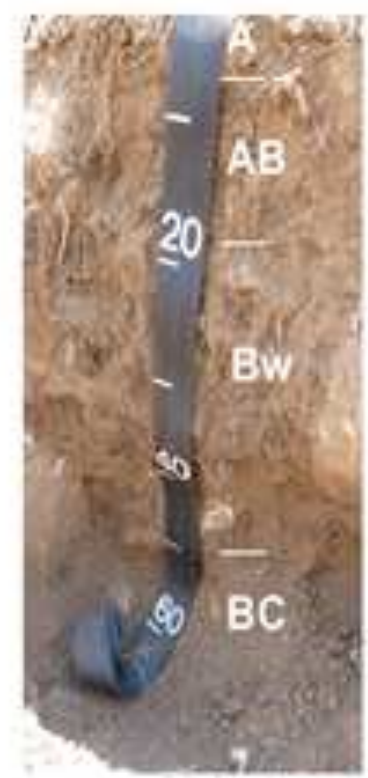

PB-1

North Fork

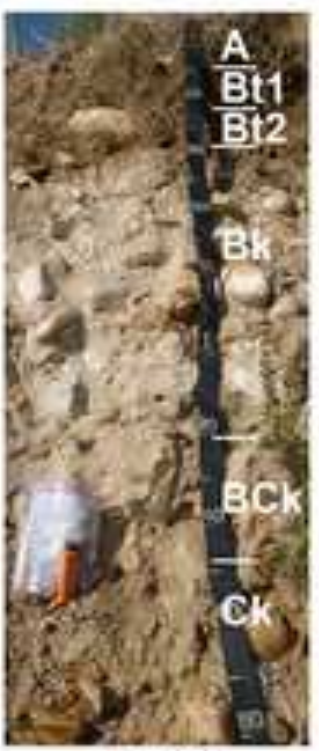

LWS

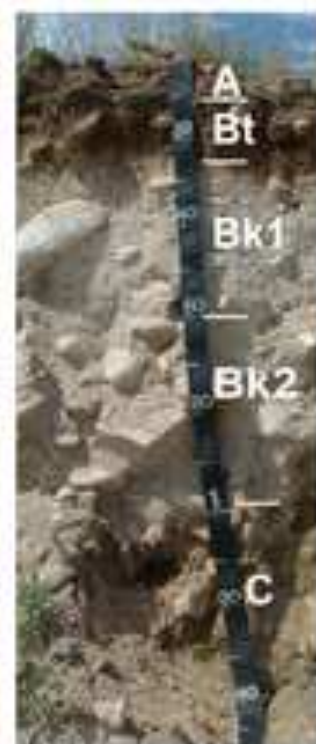

SB

Middle Fork

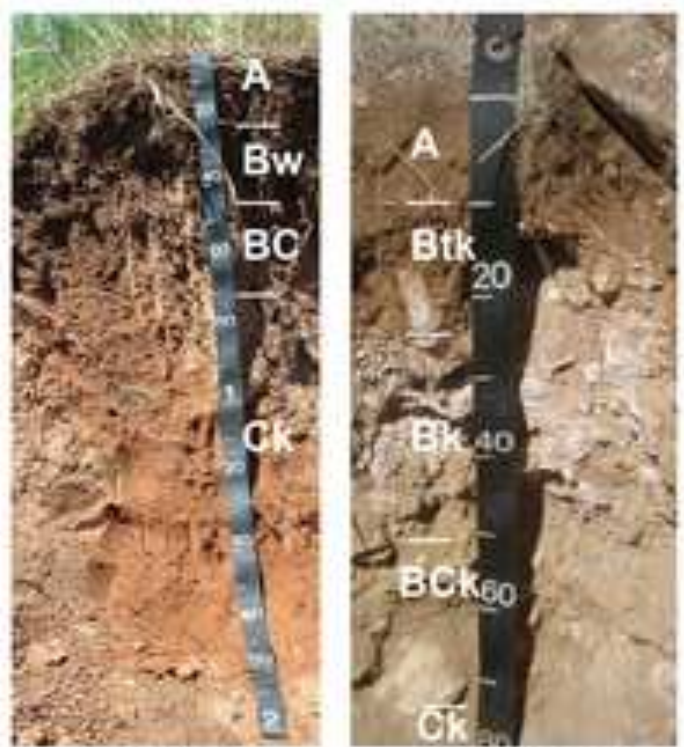

GaIPD
GR-13-1

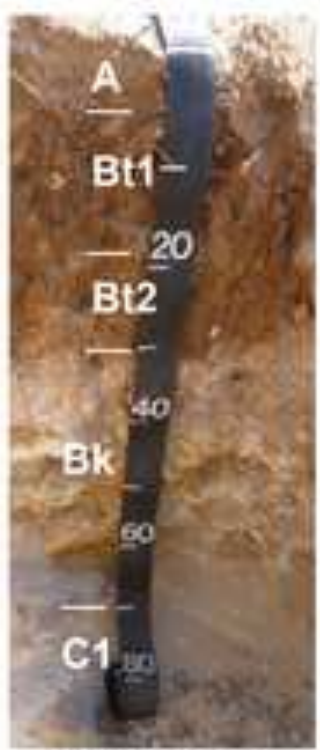

GR-13-2

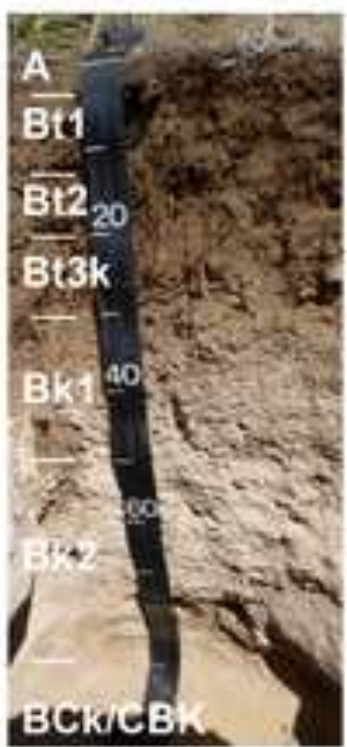

PB-2 
A)

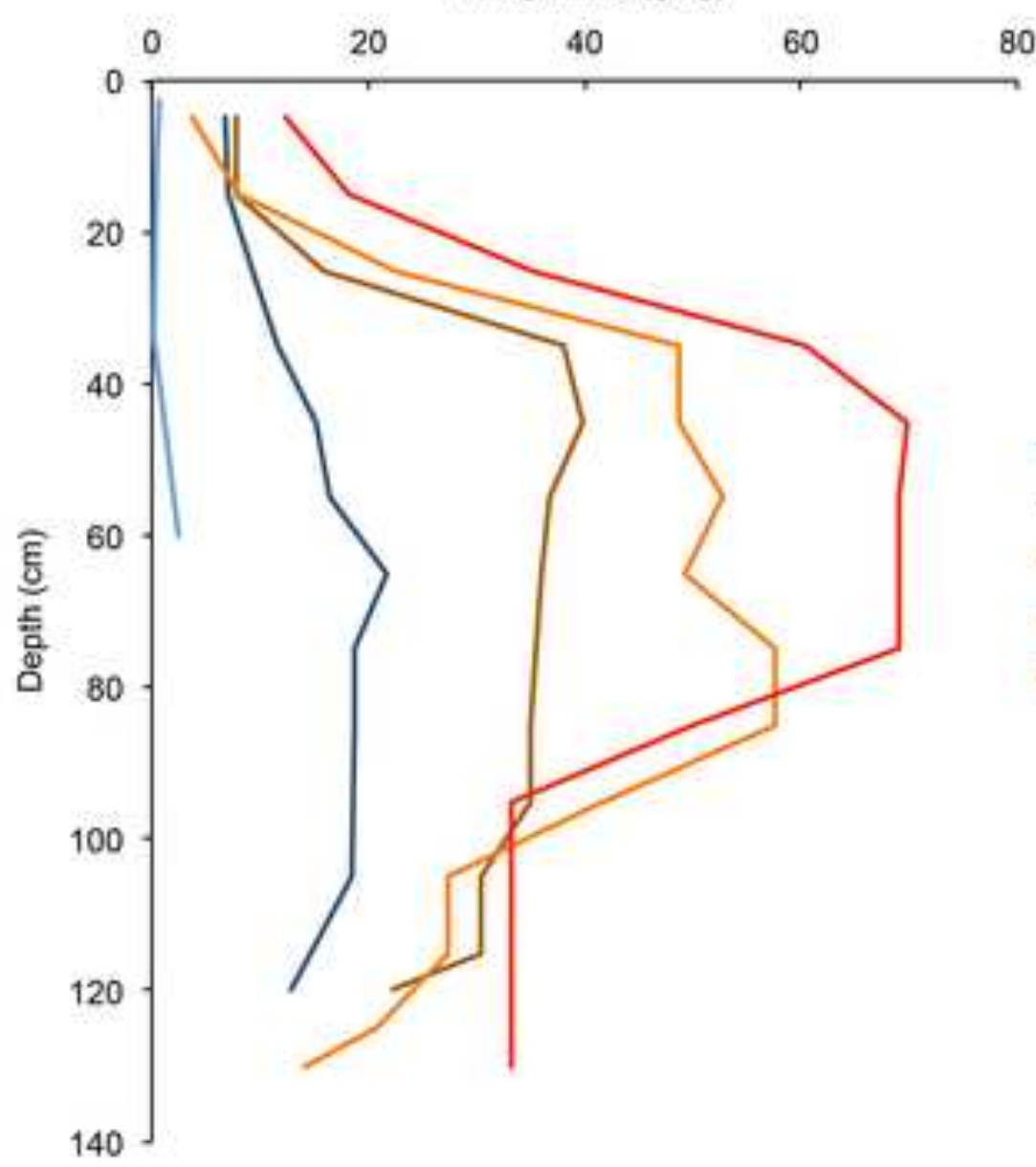

B)

80

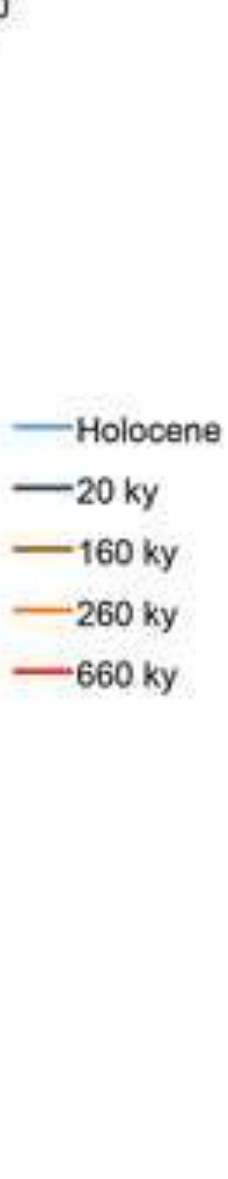

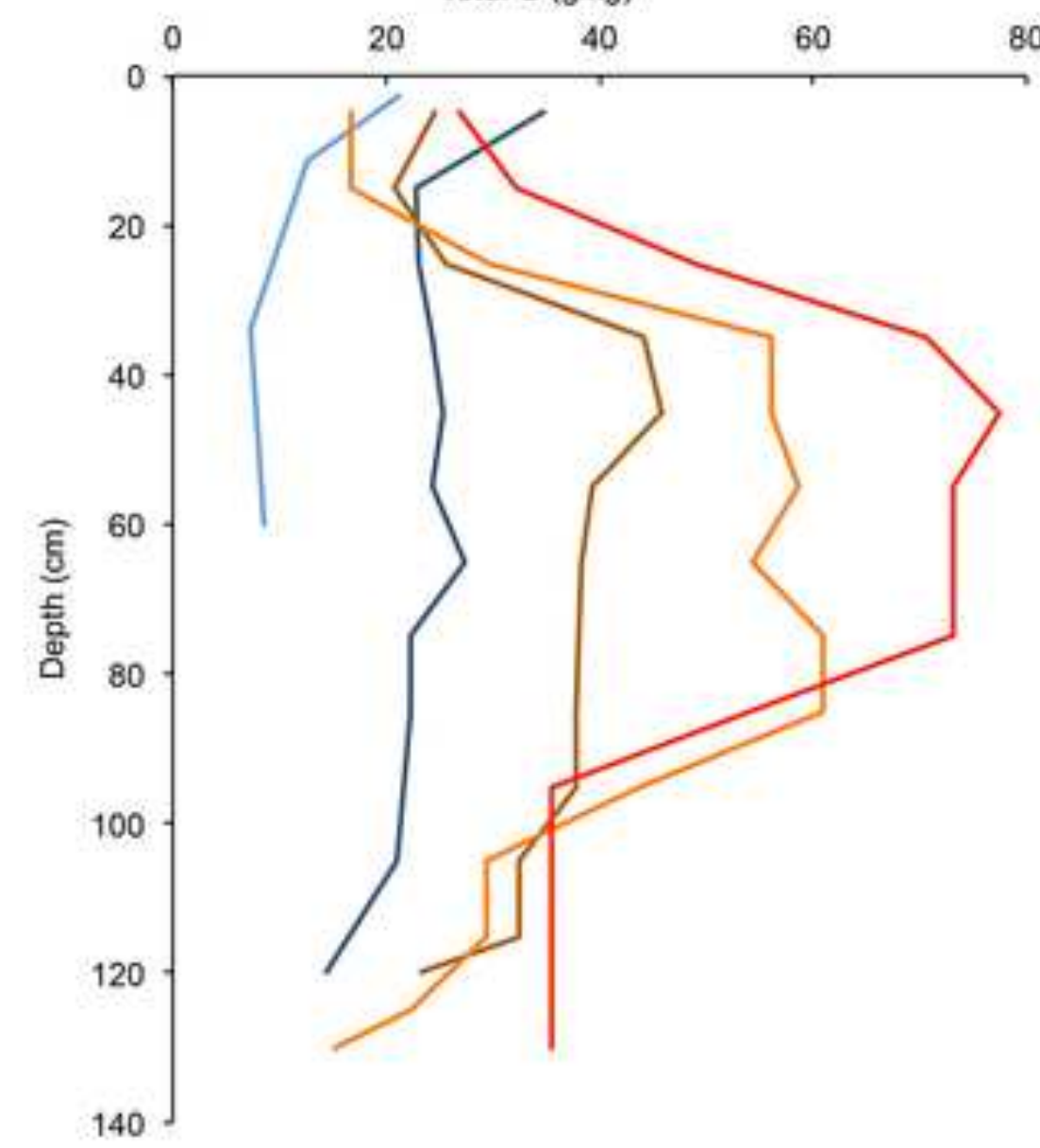


A) Ahorizon

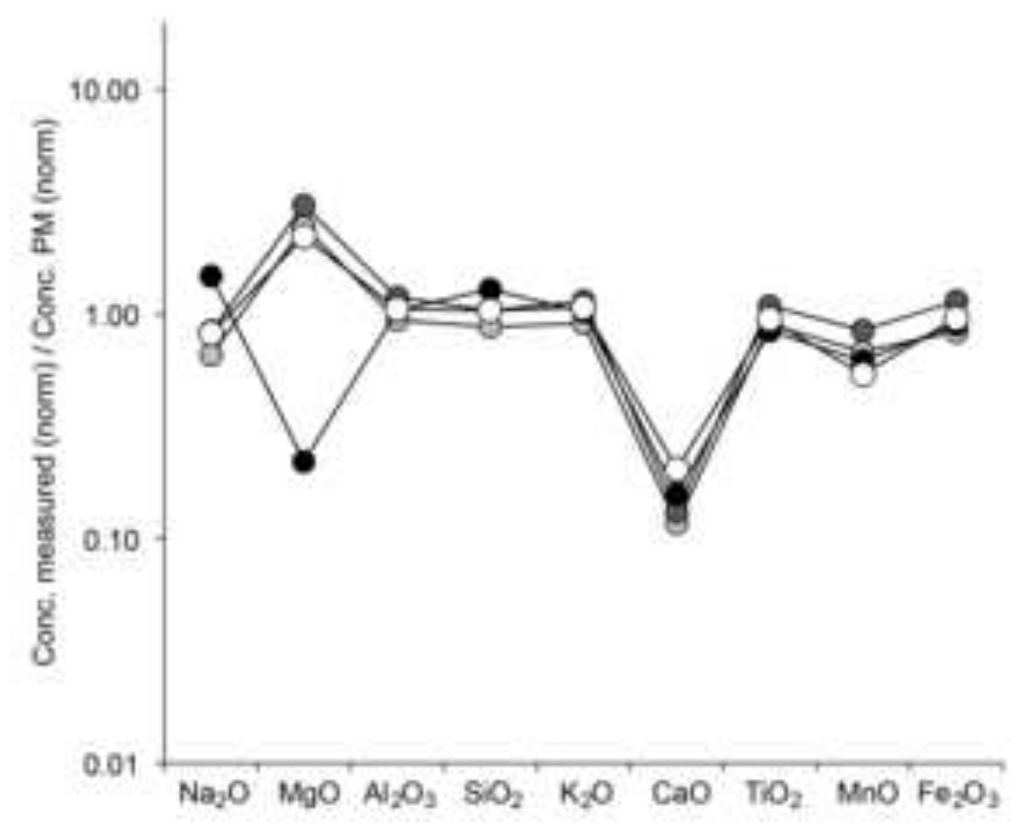

C) $B(k)$ horizon

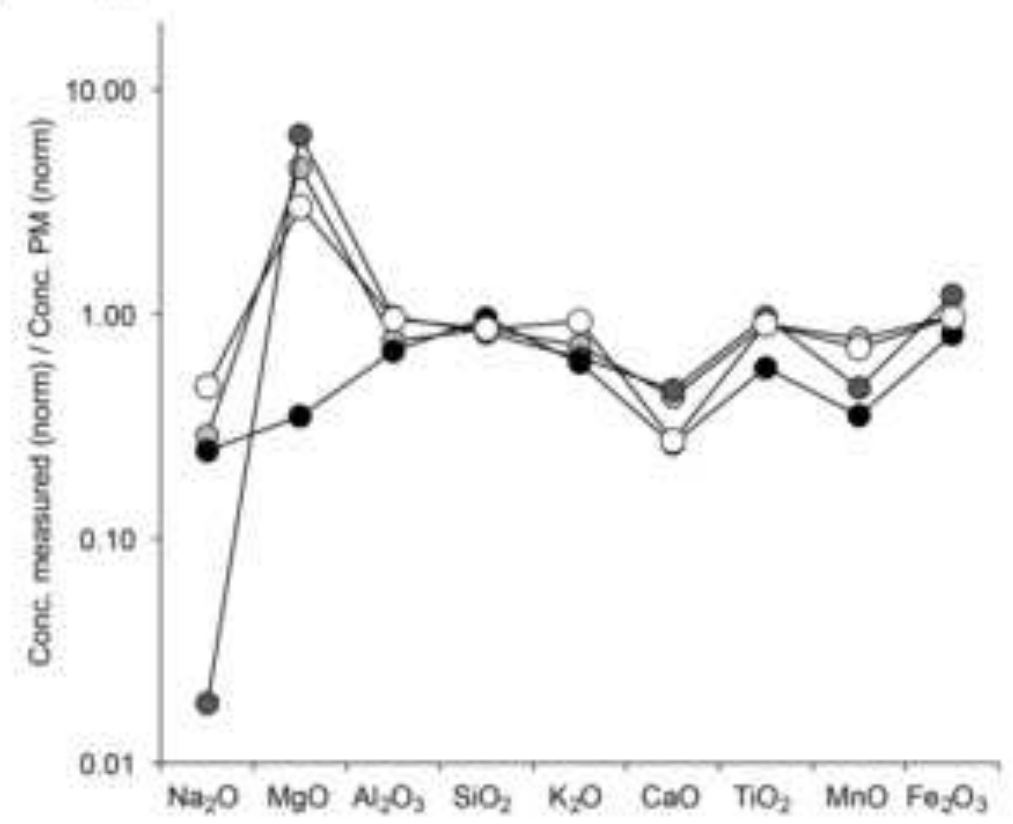

B) Ahorizon
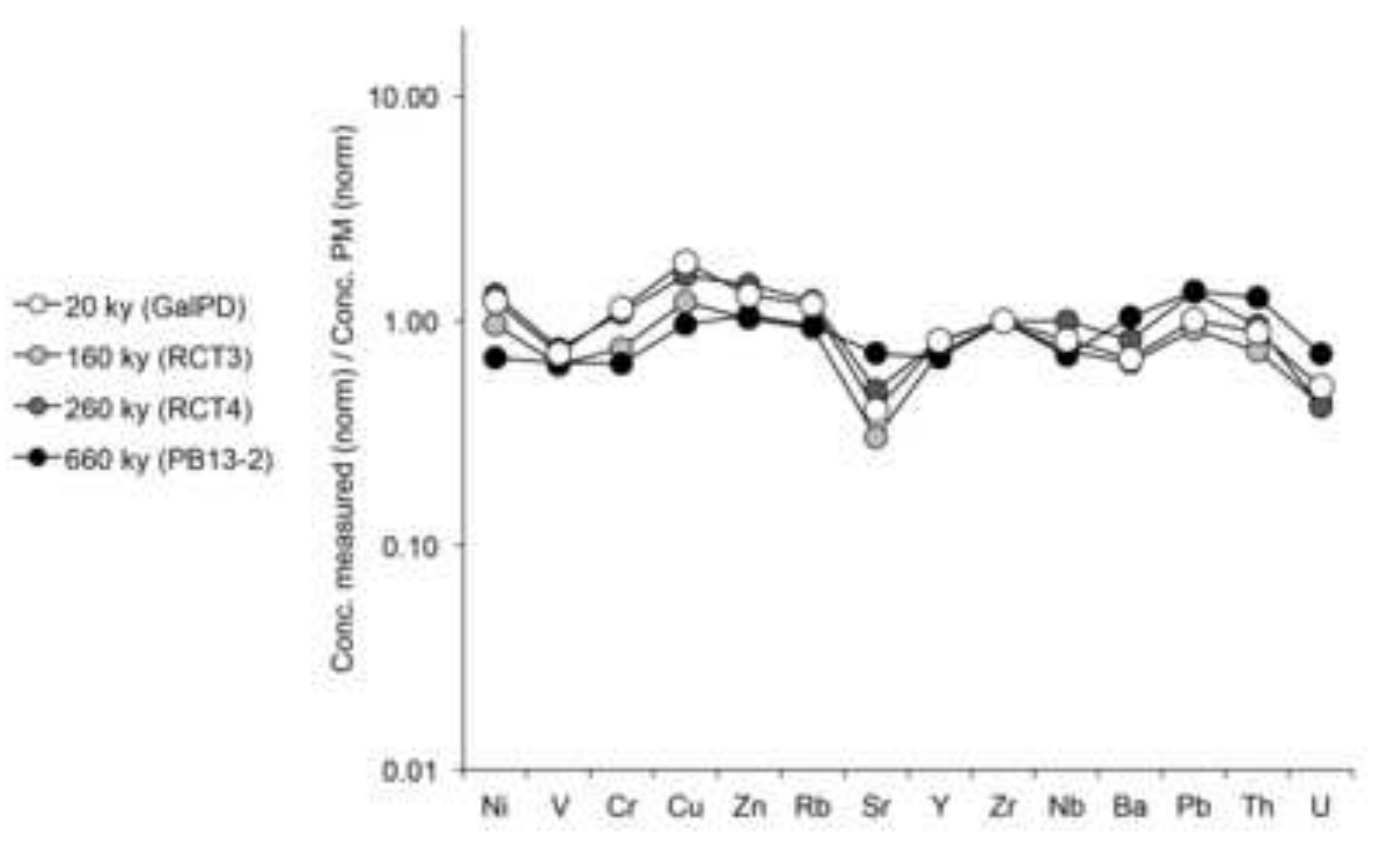

)) $B(k)$ horizon
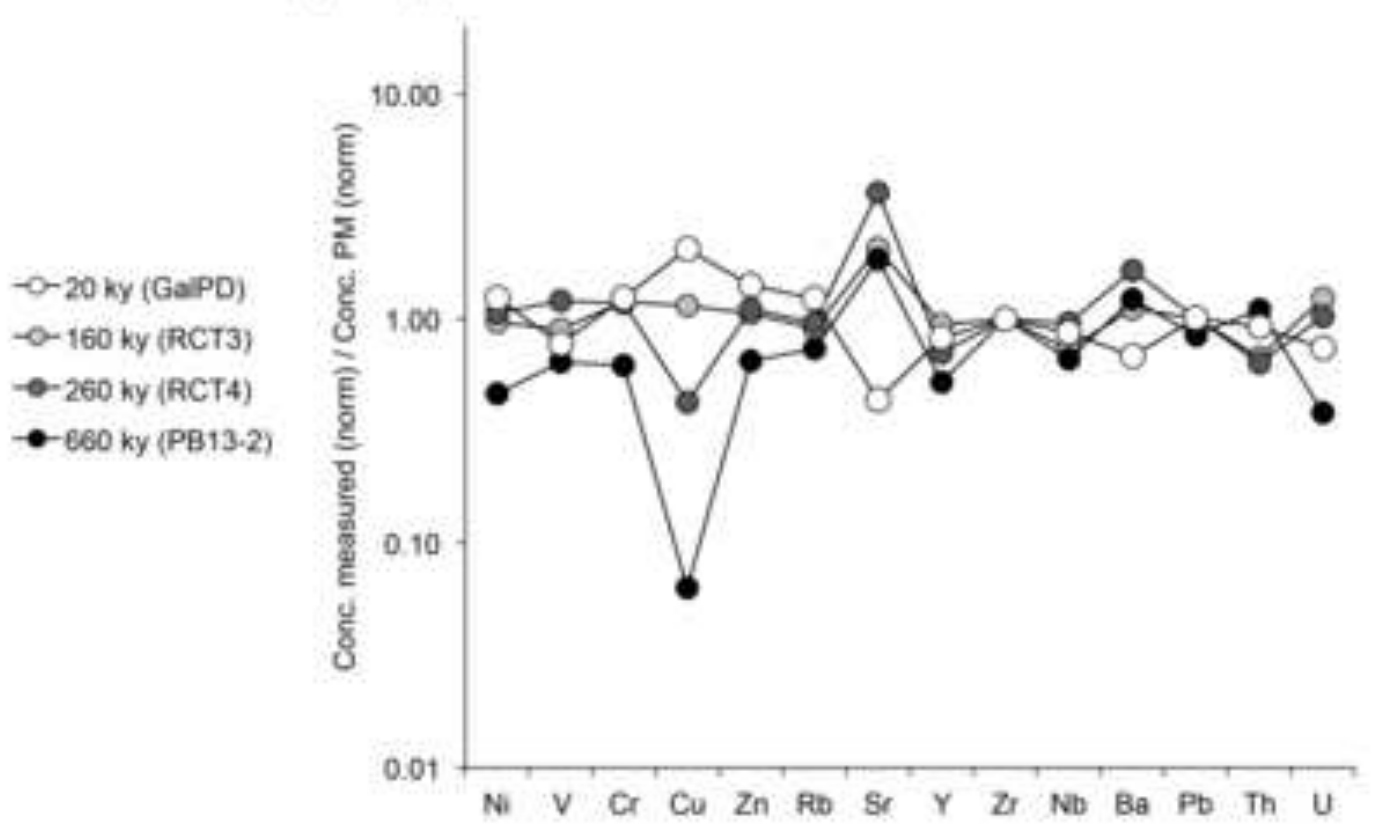
A) A-horizon

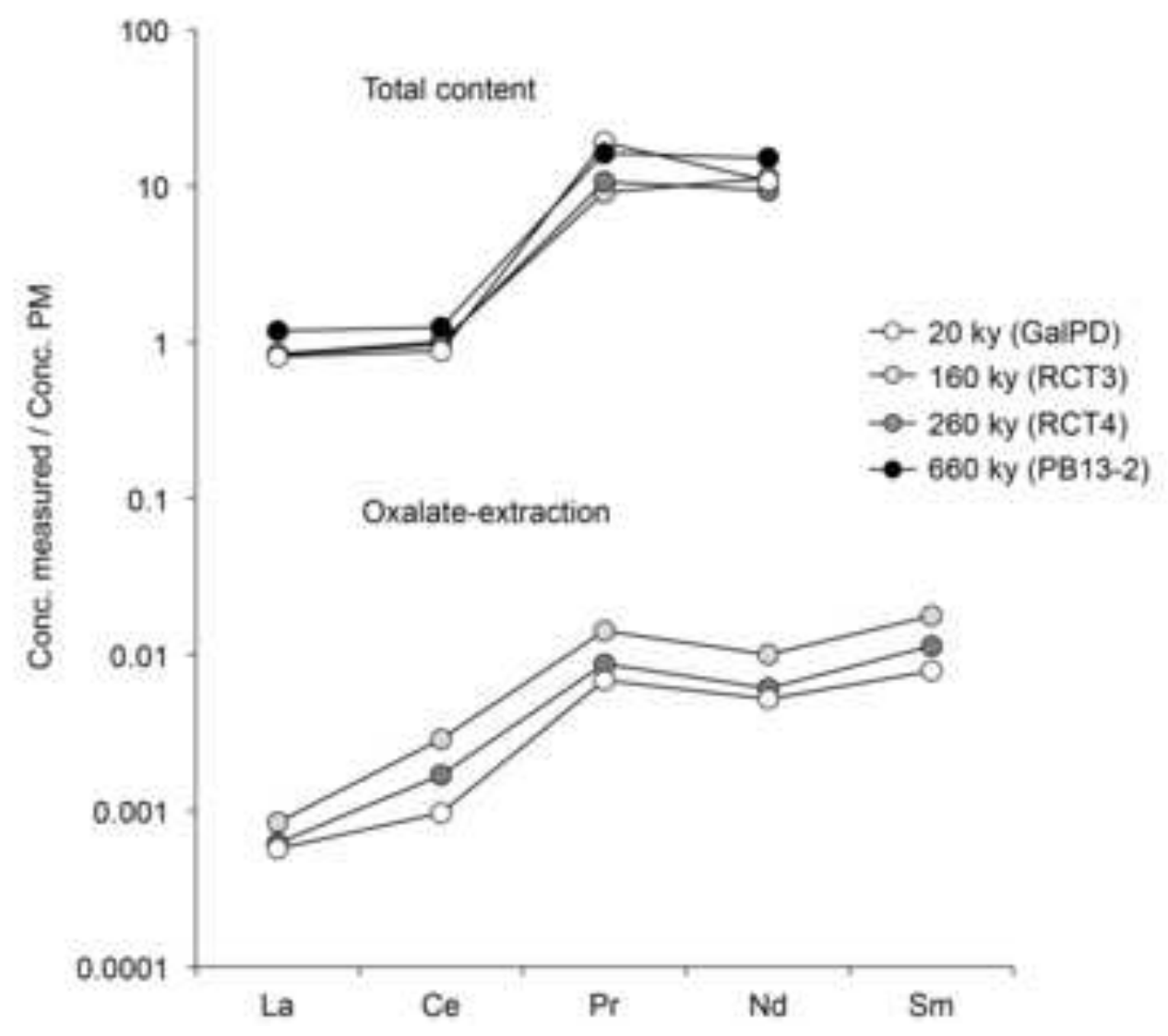

B) $B(k)$-horizon

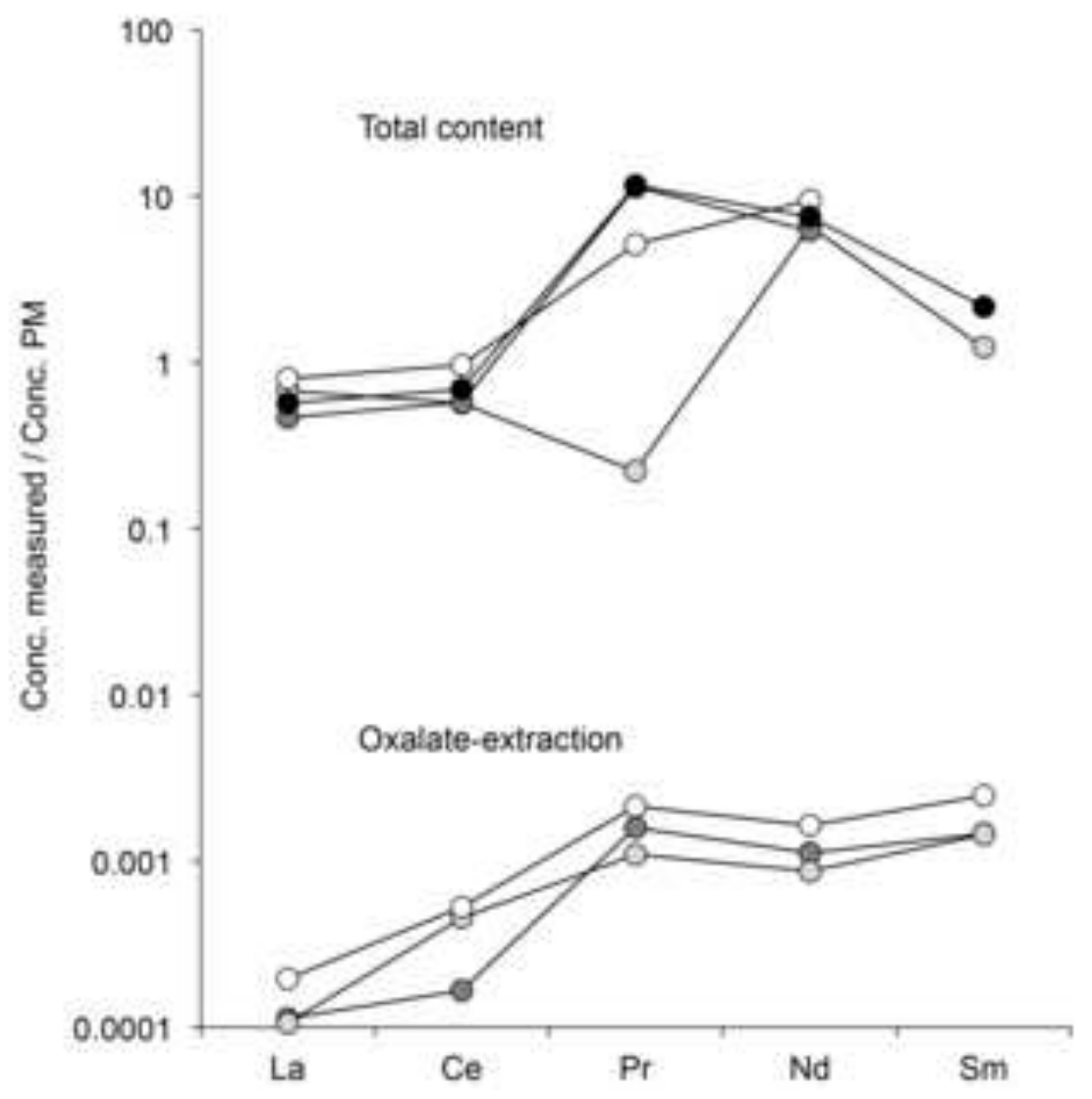


A)

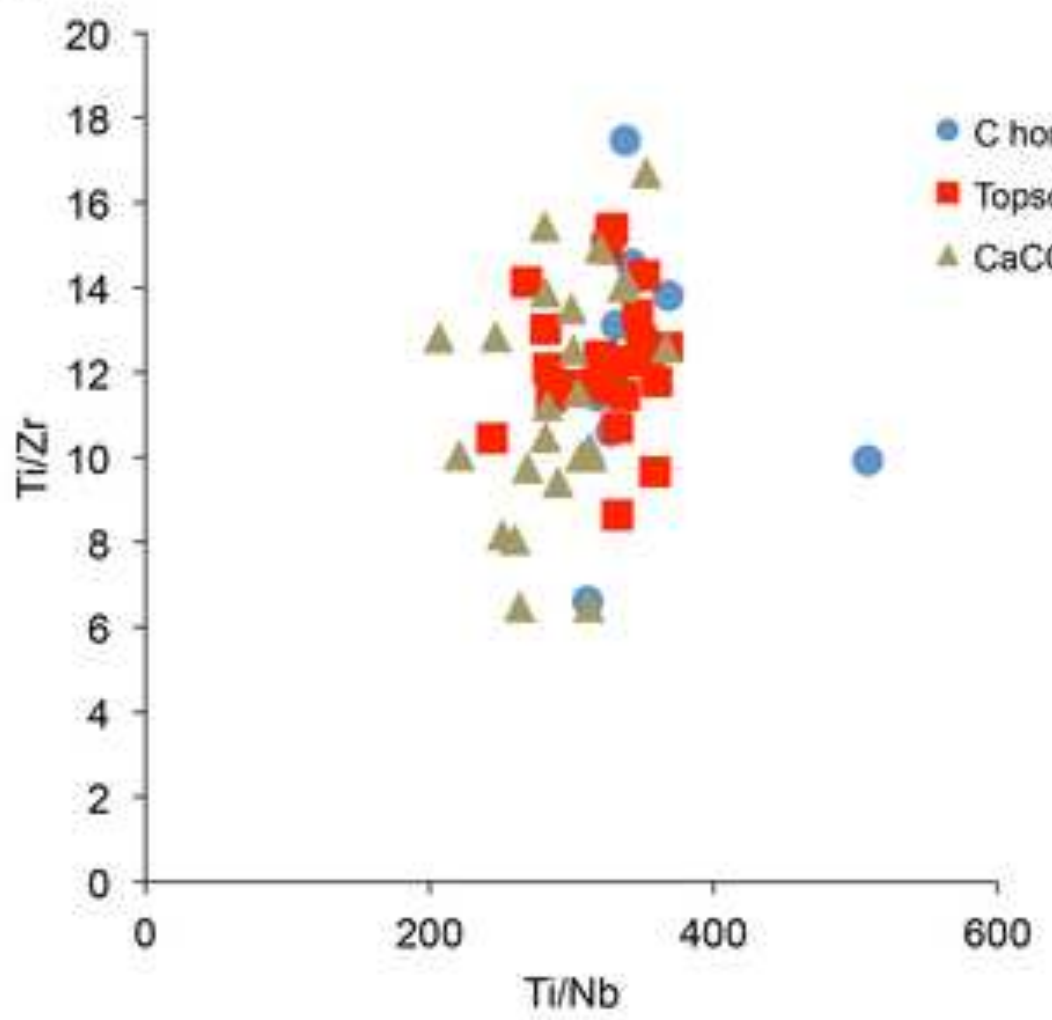

B)

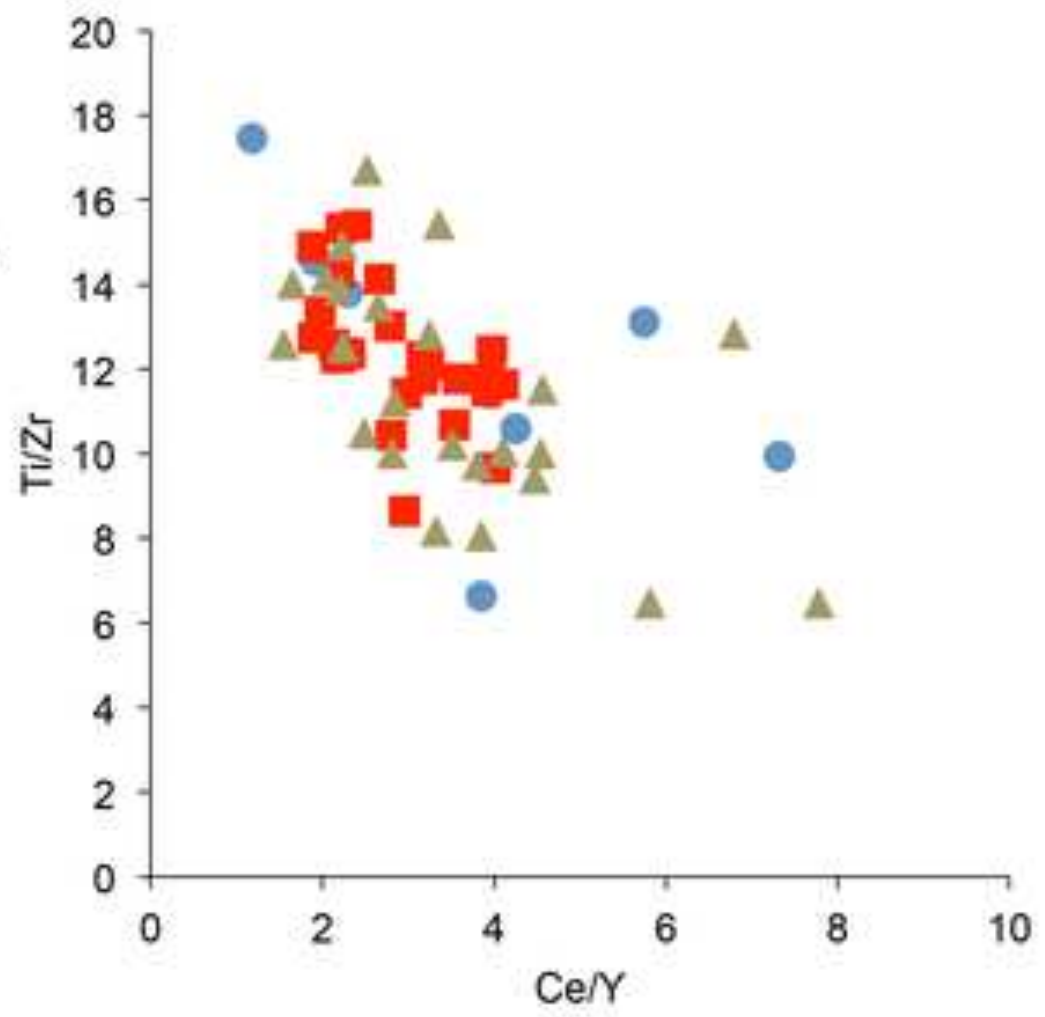




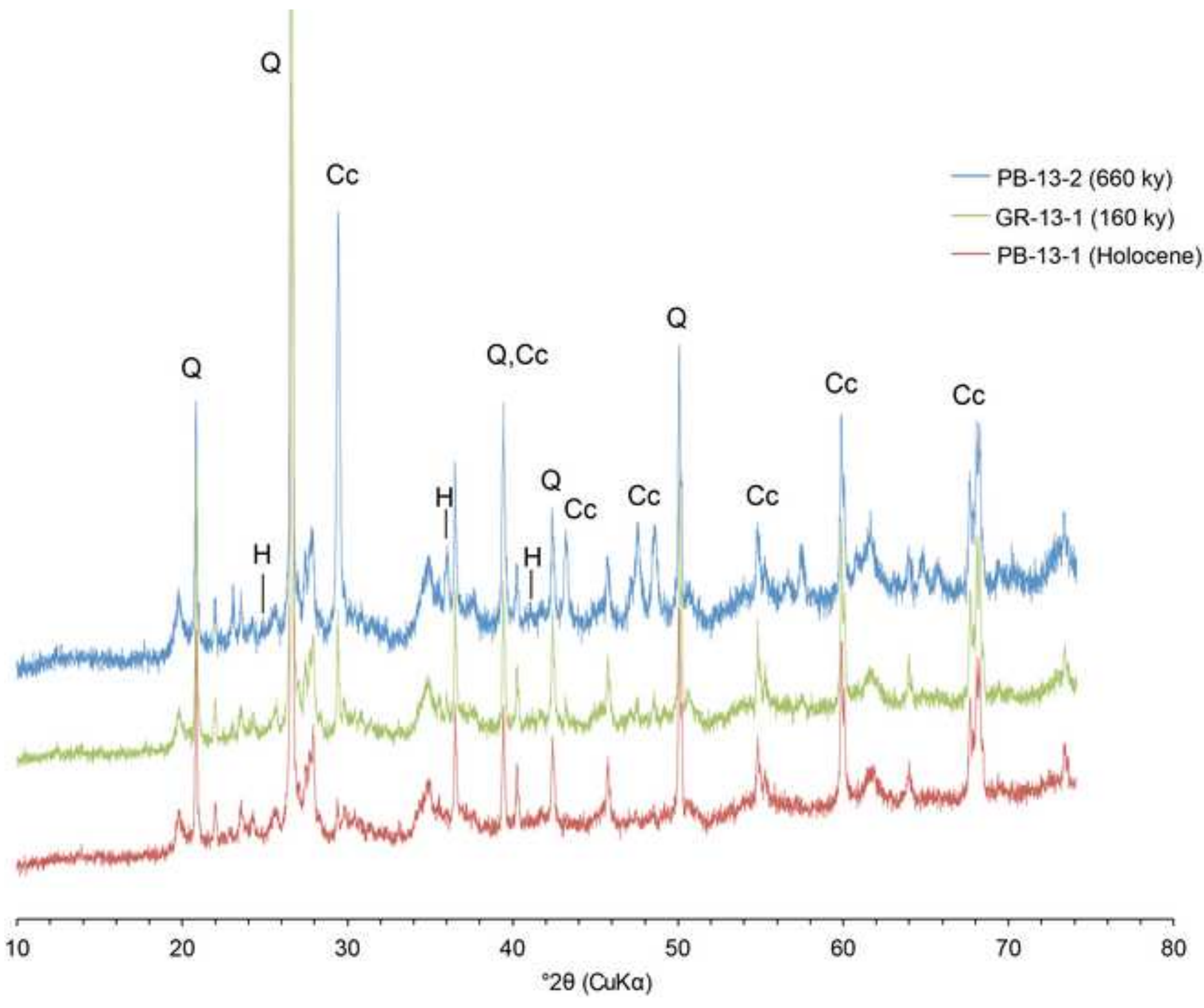


Click here to download high resolution image

A)

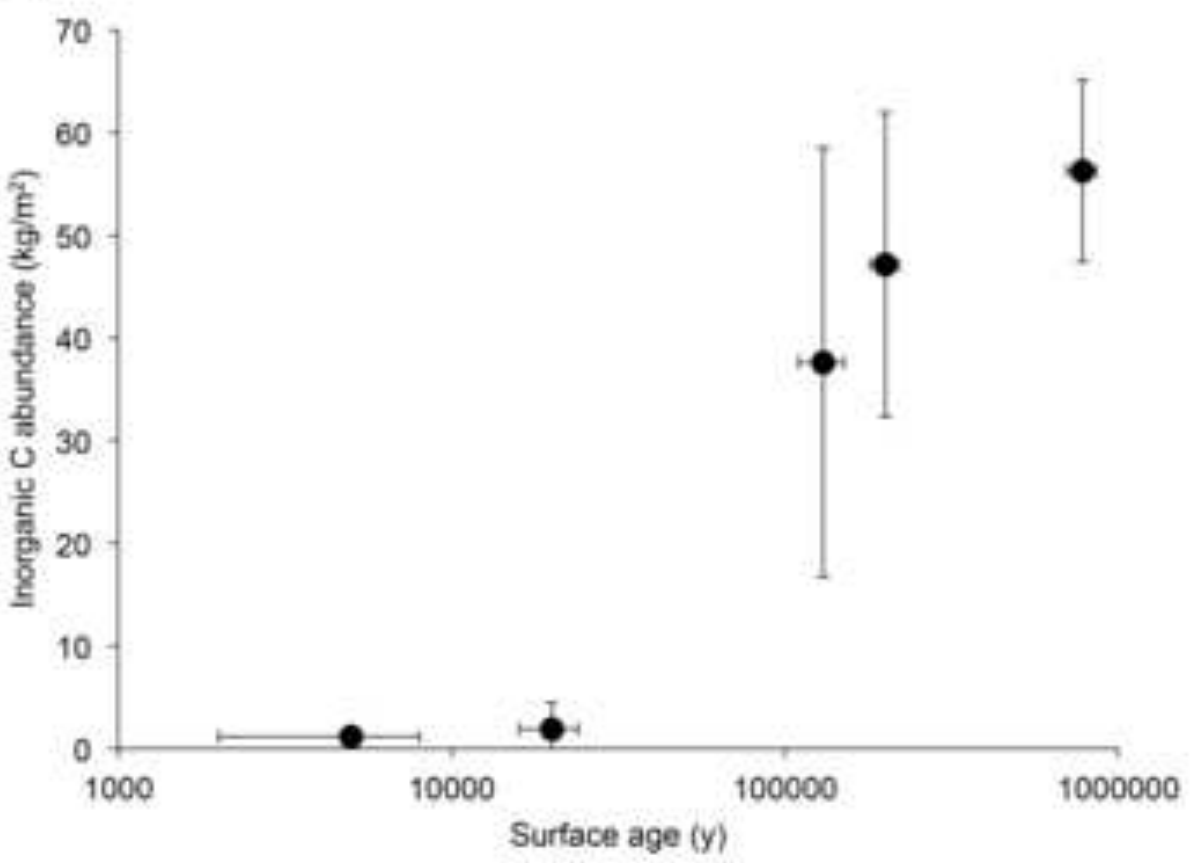

B)

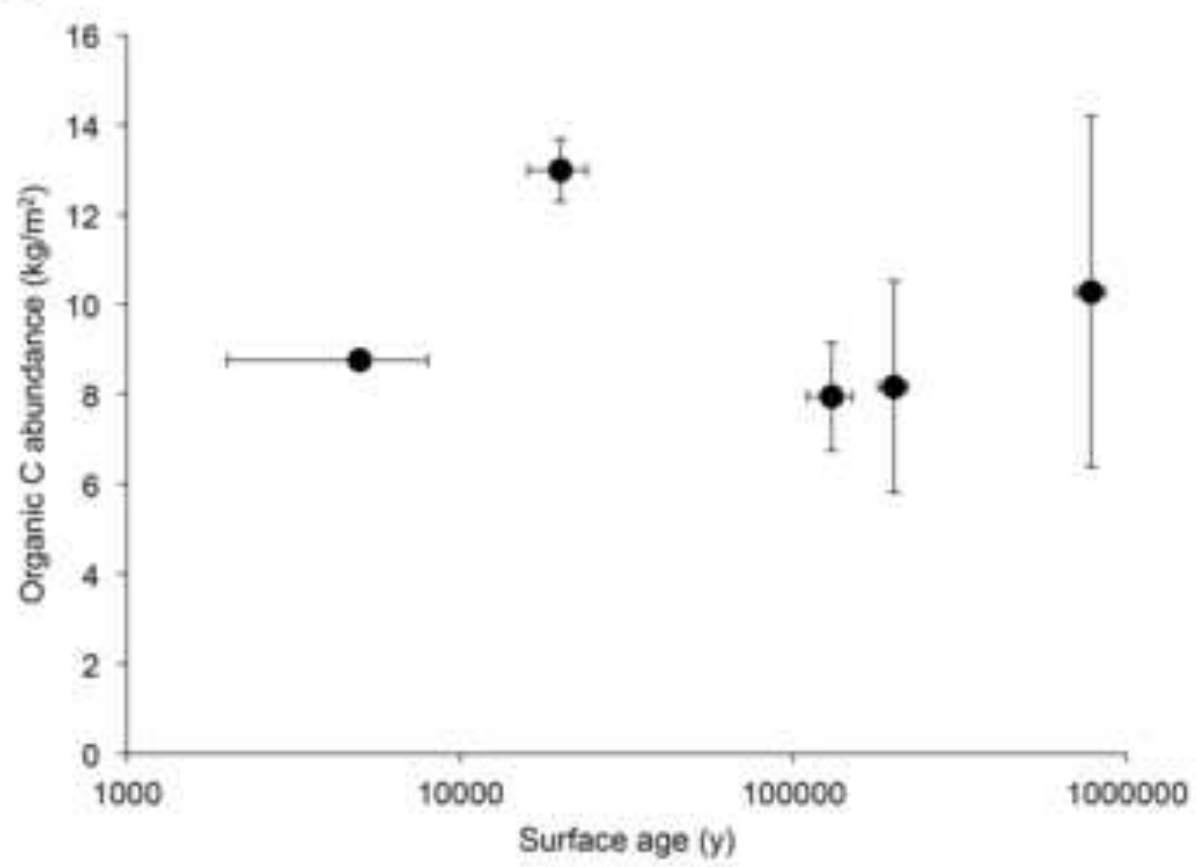


Figure 10

Click here to download high resolution image
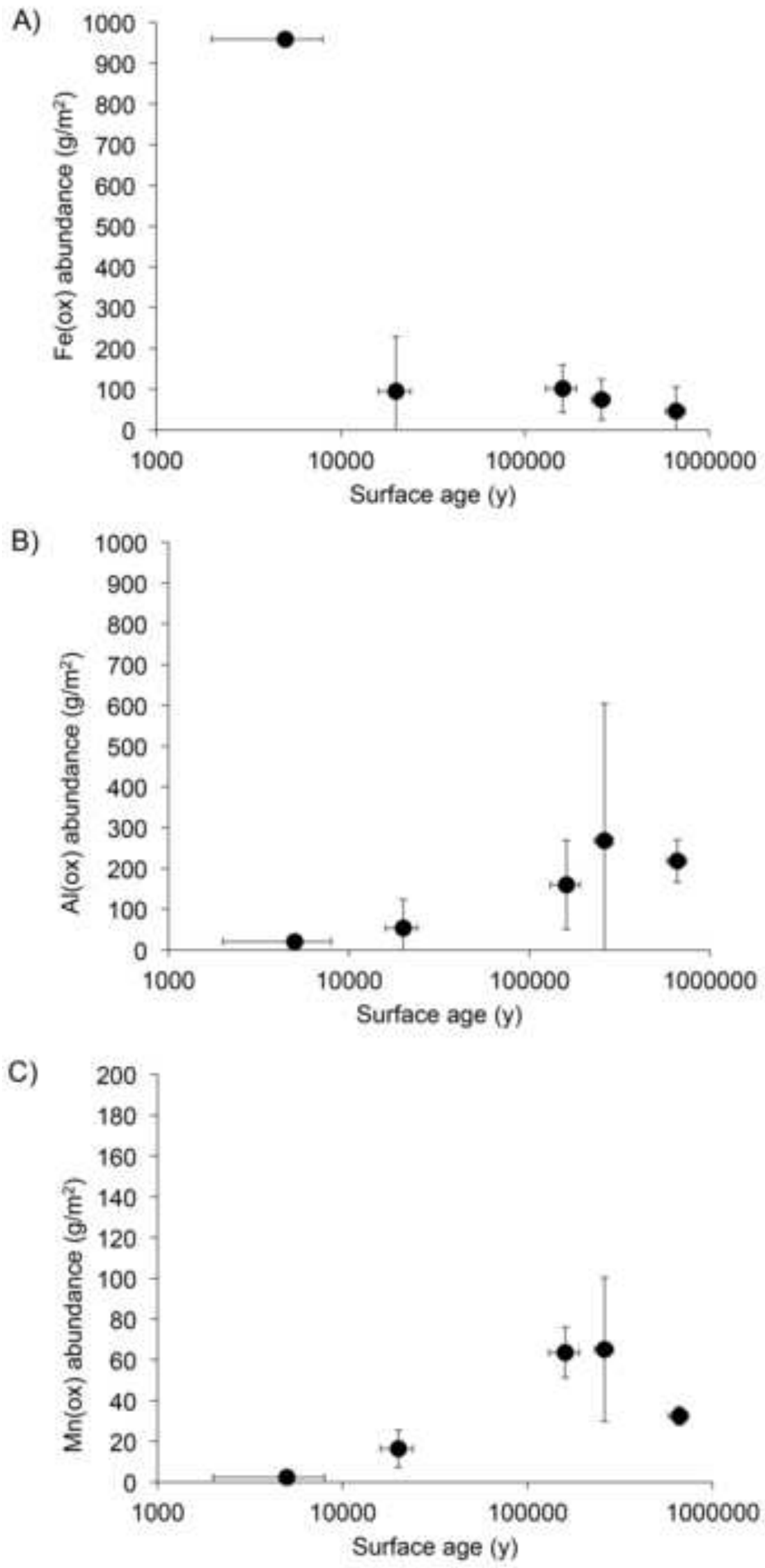
Click here to download high resolution image

A)

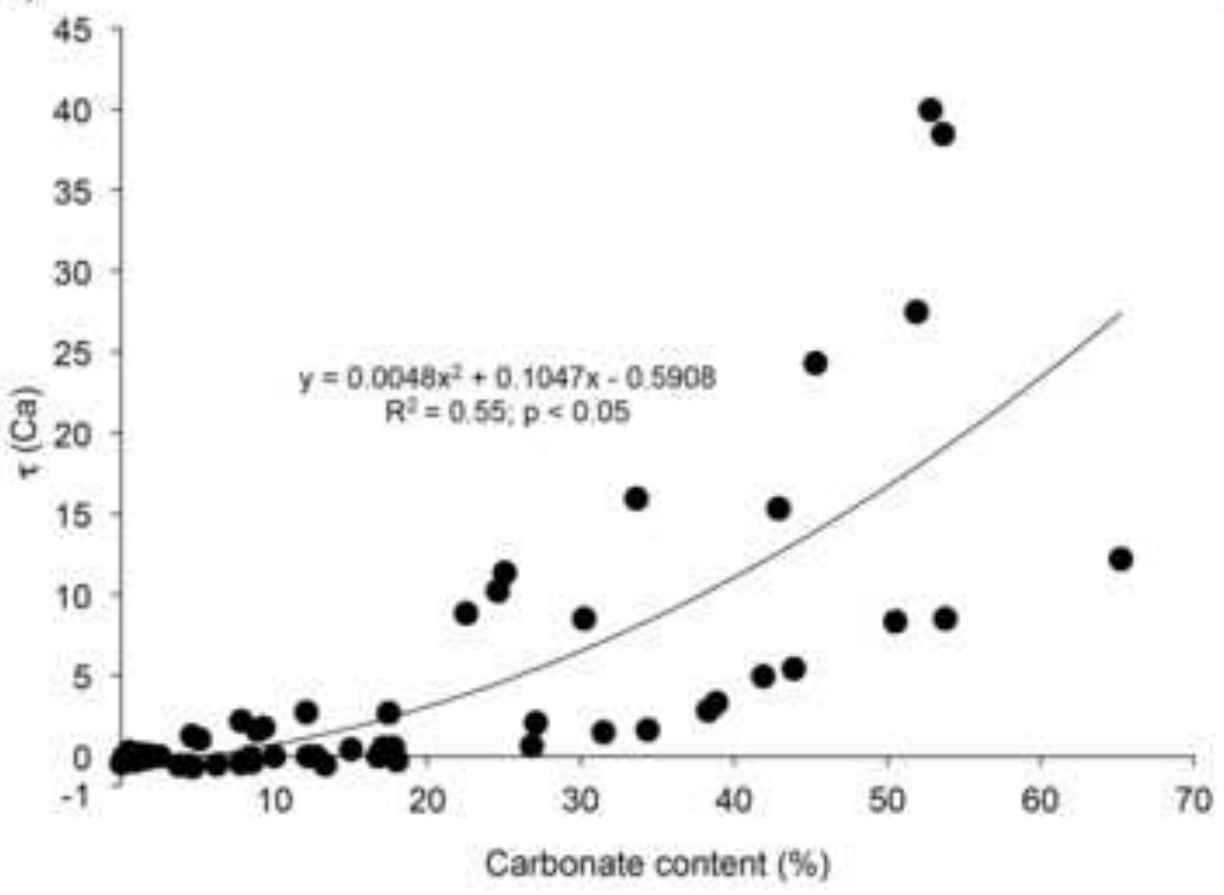

B)

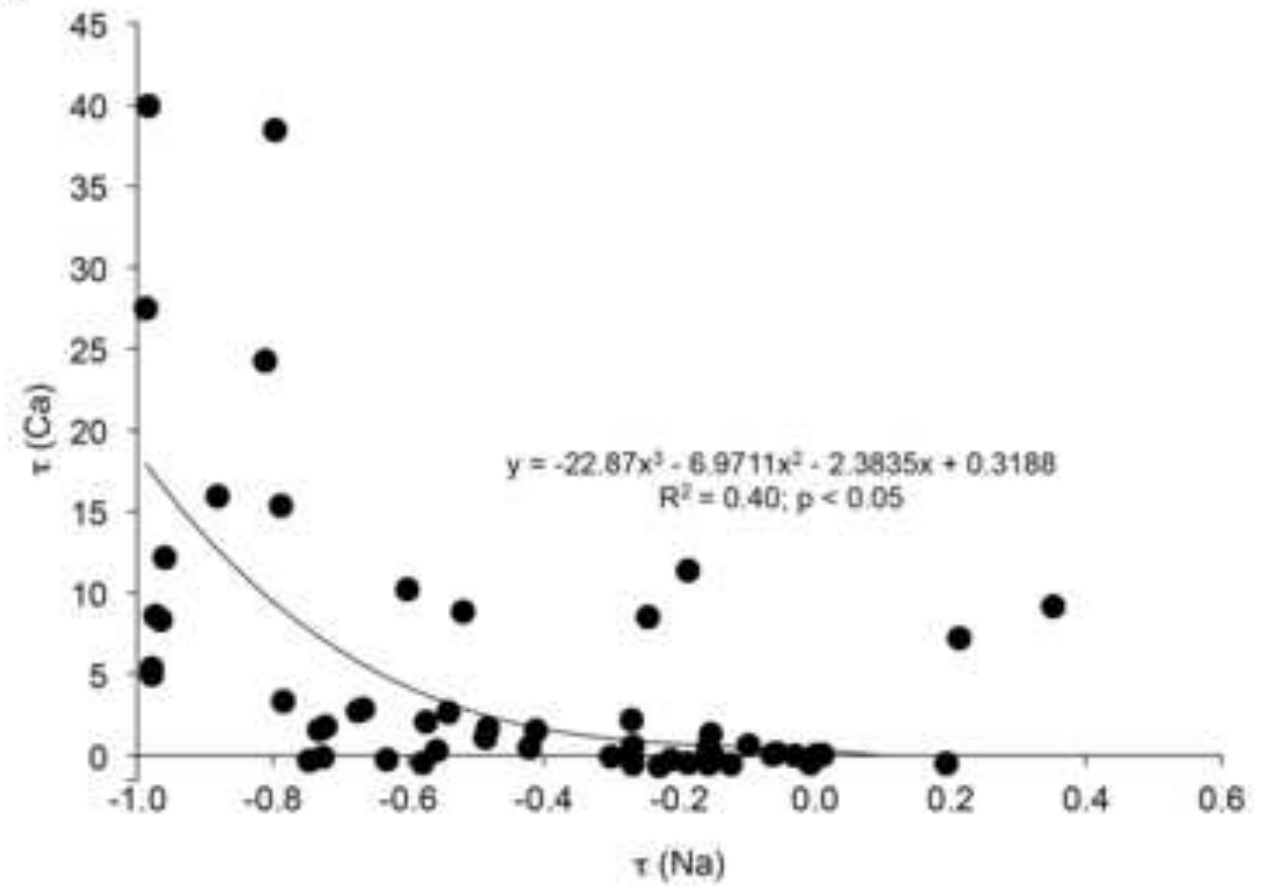


Click here to download high resolution image

A)

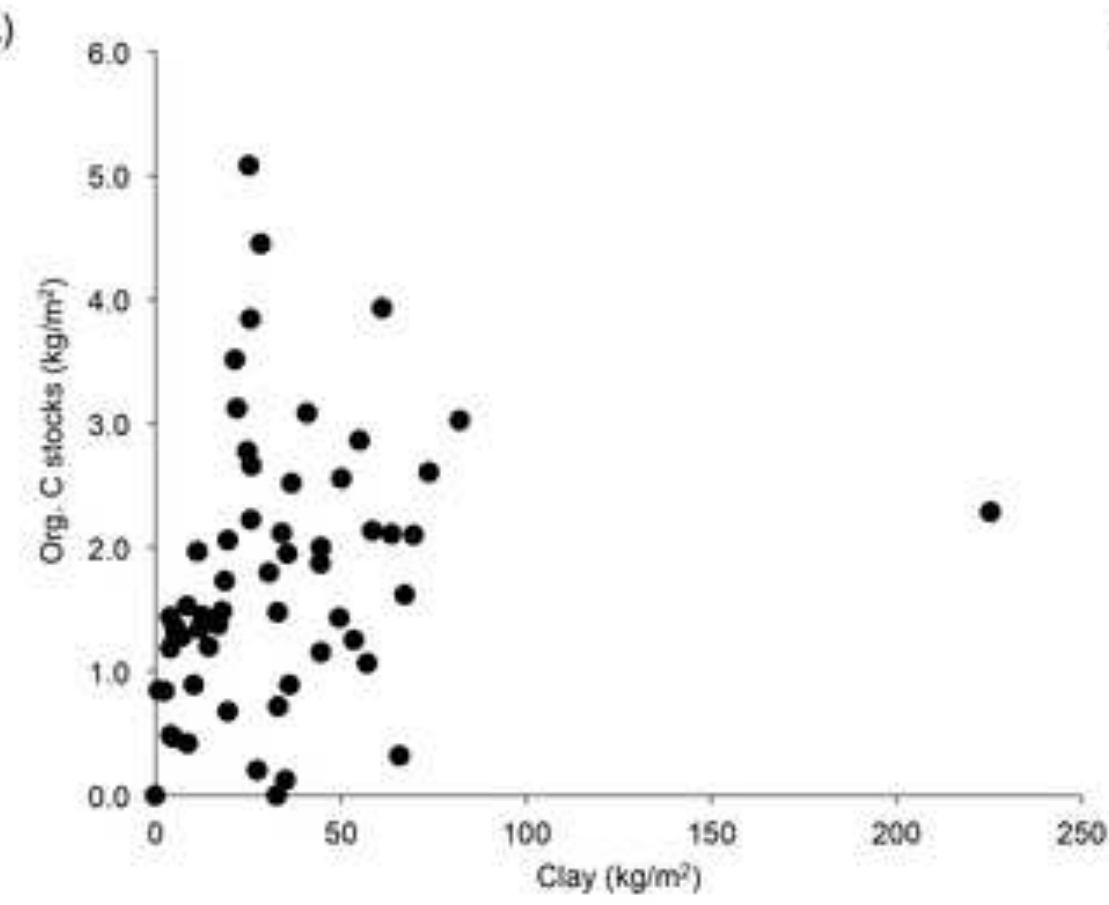

C)

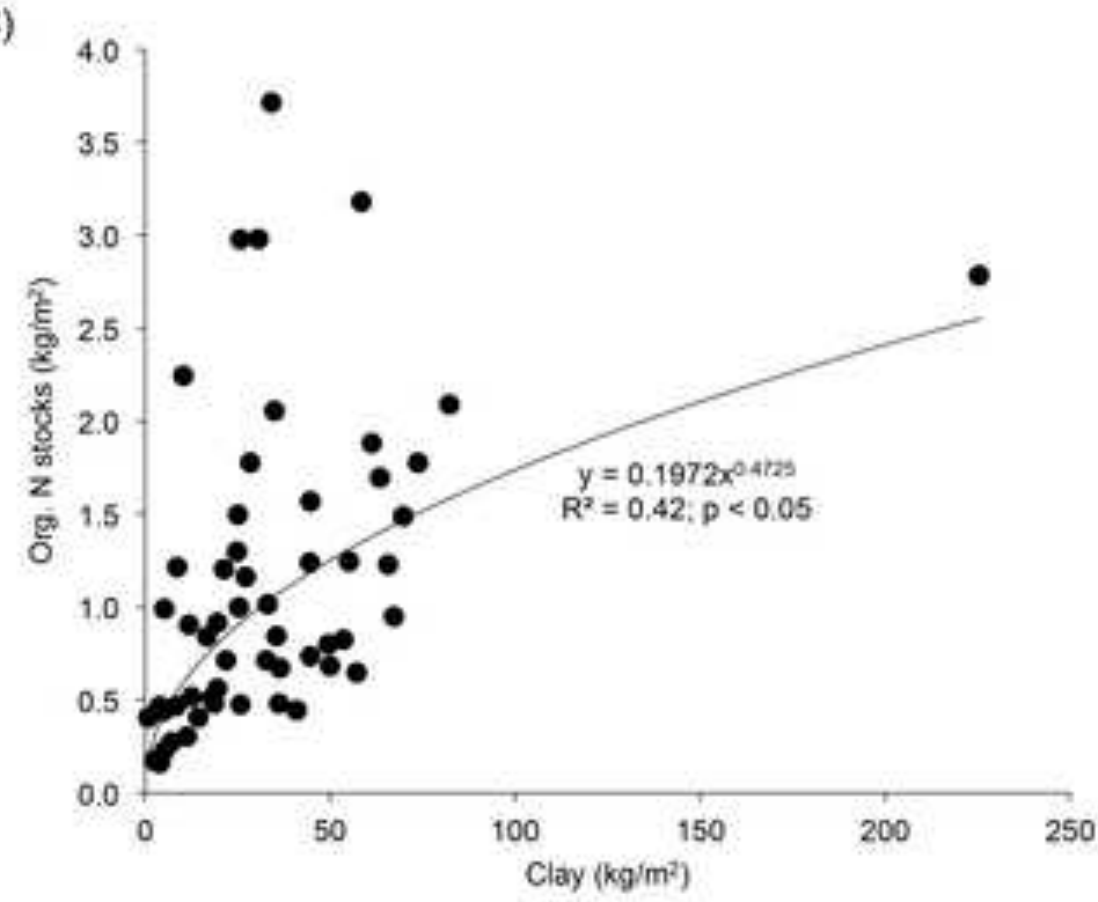

B)

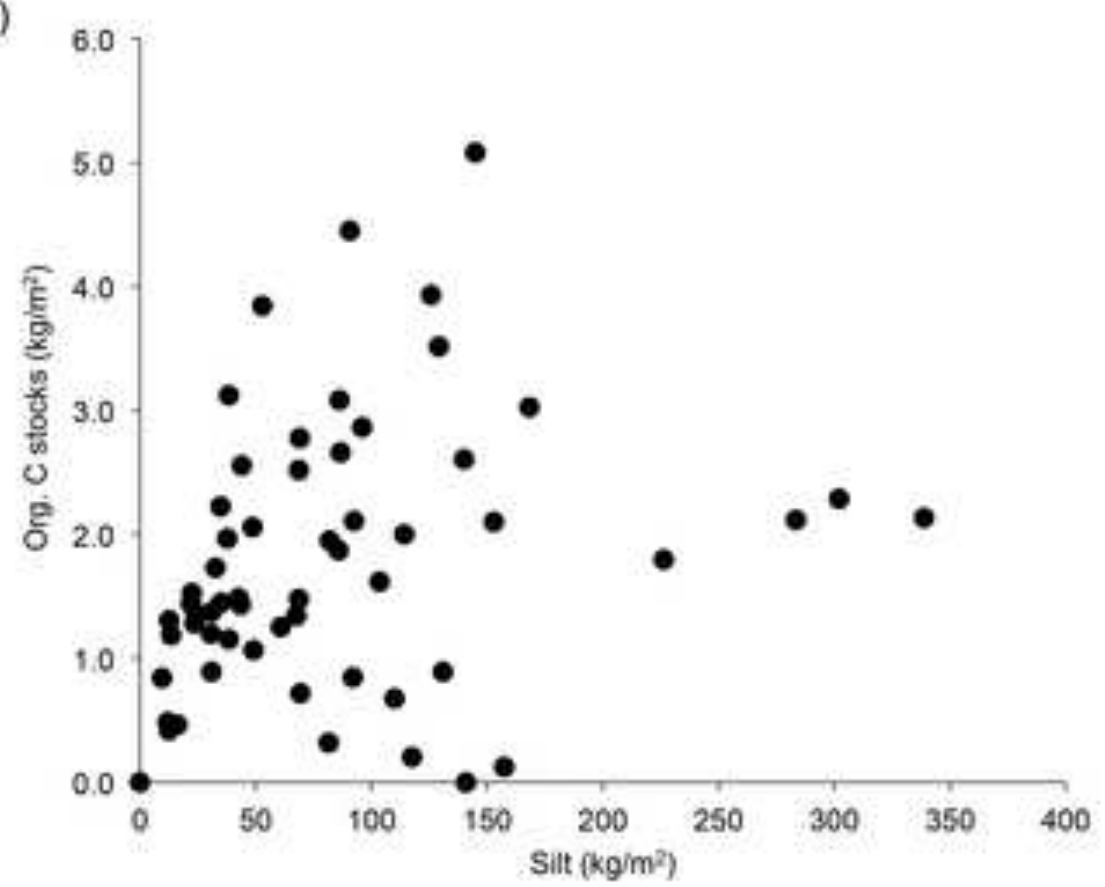

D)

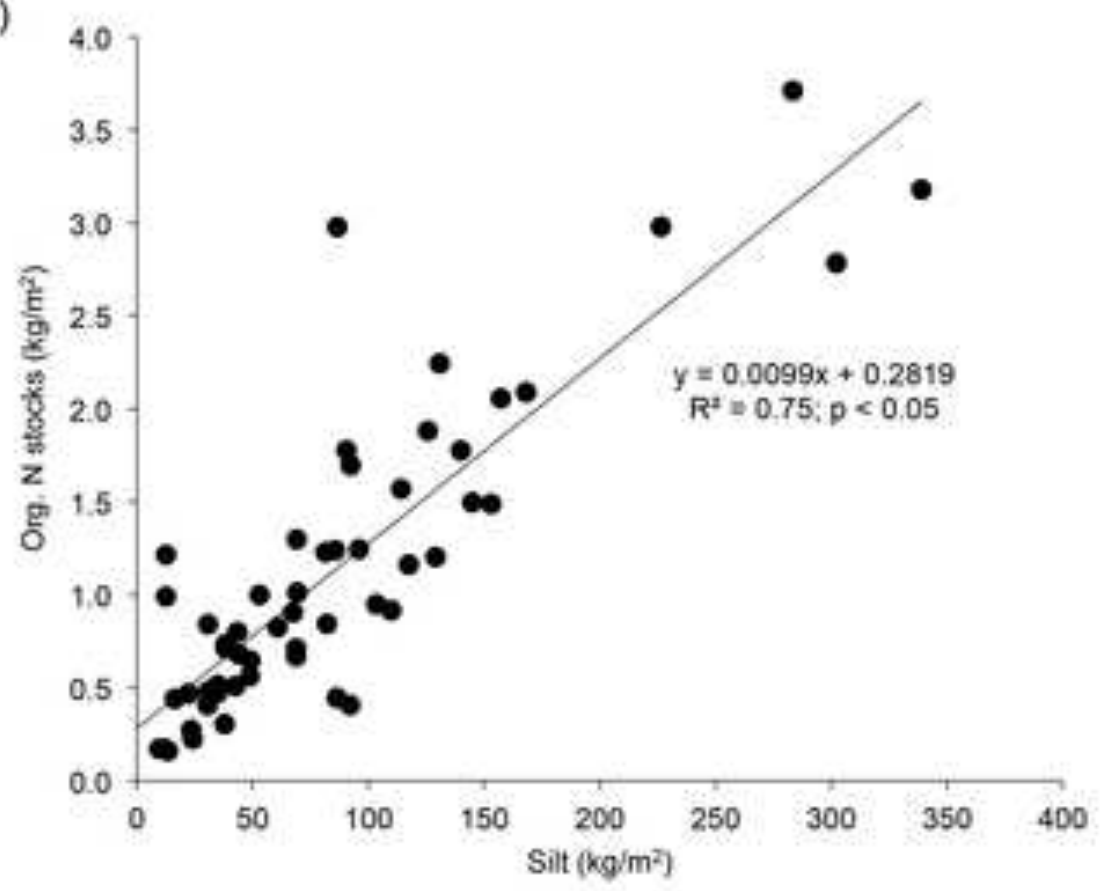


Table 1. Characteristics of the terrace sites along the North Fork, Middle Fork and Little Popo Agie rivers, Wind River Range.

\begin{tabular}{|c|c|c|c|c|c|c|c|c|}
\hline $\begin{array}{l}\text { Site / } \\
\text { Soil profile }\end{array}$ & $\begin{array}{c}\text { Longitude } \\
{ }^{\circ} \mathrm{E}\end{array}$ & $\begin{array}{c}\text { Latitude } \\
{ }^{\circ} \mathrm{N}\end{array}$ & $\begin{array}{c}\text { Elevation } \\
\text { m asl }\end{array}$ & $\begin{array}{c}\text { Parent } \\
\text { Material* }^{*}\end{array}$ & Vegetation & $\begin{array}{c}\text { Terrace age }^{1)} \\
\text { ky }\end{array}$ & $\begin{array}{l}\text { MAP }^{2)} \\
\text { mm/year }\end{array}$ & $\begin{array}{c}\mathrm{MAT}^{2)} \\
{ }^{\circ} \mathrm{C}\end{array}$ \\
\hline \multicolumn{9}{|l|}{$\begin{array}{l}\text { Little PopoAgie - } \\
\text { Red Canyon }\end{array}$} \\
\hline $\mathrm{RCT} 2$ & $108^{\circ} 39^{\prime} 54^{\prime \prime}$ & $42^{\circ} 40^{\prime} 39^{\prime \prime}$ & 1722 & $\mathrm{RP} / \mathrm{C}$ & Grass, Sagebrush & $20( \pm 4)$ & $250-380$ & 6.7 \\
\hline RCT3 & $108^{\circ} 40^{\prime} 10^{\prime \prime}$ & $42^{\circ} 40^{\prime} 40^{\prime \prime}$ & 1750 & $\mathrm{RP} / \mathrm{C}$ & Grass, Sagebrush & $160( \pm 30)$ & $250-380$ & 6.6 \\
\hline RCT4 & $108^{\circ} 40^{\prime} 10^{\prime \prime}$ & $42^{\circ} 40^{\prime} 24^{\prime \prime}$ & 1768 & $\mathrm{RP} / \mathrm{C}$ & Grass, Sagebrush & $260( \pm 30)$ & $250-380$ & 6.4 \\
\hline RCT5 & $108^{\circ} 40^{\prime} 19^{\prime \prime}$ & $42^{\circ} 40^{\prime} 17^{\prime \prime}$ & 1795 & $\mathrm{RP} / \mathrm{C}$ & Grass, Sagebrush & $660( \pm 40)$ & $250-380$ & 6.3 \\
\hline \multicolumn{9}{|c|}{ Middle Fork - Lander } \\
\hline LWS-13-1 & $108^{\circ} 43^{\prime} 34^{\prime \prime}$ & $42^{\circ} 49^{\prime} 47^{\prime \prime}$ & 1643 & G & Grass, Sage, riparian & $160( \pm 30)$ & 330 & 7.2 \\
\hline SB & $108^{\circ} 43^{\prime} 12^{\prime \prime}$ & $42^{\circ} 49^{\prime} 30^{\prime \prime}$ & 1676 & G & Grass, Sagebrush & $260( \pm 30)$ & 330 & 7.0 \\
\hline \multicolumn{9}{|l|}{ North Fork } \\
\hline PB-13-1 & $108^{\circ} 53^{\prime} 16^{\prime \prime}$ & $42^{\circ} 52^{\prime} 08^{\prime \prime}$ & 1826 & OG & Grass, Sage, riparian & $5( \pm 3)$ & $250-380$ & 6.1 \\
\hline GalPD & $108^{\circ} 51^{\prime} 39^{\prime \prime}$ & $42^{\circ} 53^{\prime} 03^{\prime \prime}$ & 1768 & $\mathrm{RP} / \mathrm{C}$ & Grass, Sage, riparian & $20( \pm 4)$ & $250-380$ & 6.4 \\
\hline GR-13-1 & $108^{\circ} 51^{\prime} 47^{\prime \prime}$ & $42^{\circ} 53^{\prime} 12^{\prime \prime}$ & 1798 & G & Grass, Sagebrush & $160( \pm 30)$ & $250-380$ & 6.3 \\
\hline GR-13-2 & $108^{\circ} 52^{\prime} 15^{\prime \prime}$ & $42^{\circ} 52^{\prime} 46^{\prime \prime}$ & 1838 & G & Grass, Sagebrush & $260( \pm 30)$ & $250-380$ & 6.0 \\
\hline PB-13-2 & $108^{\circ} 52^{\prime} 58^{\prime \prime}$ & $42^{\circ} 52^{\prime} 28^{\prime \prime}$ & 1908 & G & Grass, Sagebrush & $660( \pm 40)$ & $250-380$ & 5.6 \\
\hline
\end{tabular}

1) Ages for the $\sim 5, \sim 20, \sim 160$ and $\sim 260$ ky terraces are assigned (a) according to their local morphostratigraphic positions and (b) their correlations to previously-dated terrace units along the Wind/Bighorn river (heights above the modern channels and associated incision rates (Chadwick et al., 1997; Dahms 2010; Hancock et al., 1999; Nettleton and Chadwick, 1991; Phillips et al., 1997; Reheis, 1987). The highest terraces (soils RCT5, PB-13-2) were assigned an age of 260 ky according to their correlation to the 'Airport' terrace of the Middle Fork ('AT' of Fig. 2B), in which an ash deposit of Lava Creek age previously was reported (Anders et al., 2009; Jaworowski, 1992).

${ }^{2)}$ Data source: Massatti (2007), Dahms et al. (2012), PRISM Climate Group (2014)

${ }^{*} \mathrm{G}=$ granitic alluvium; $\mathrm{RP} / \mathrm{C}=$ Red Peak/Chugwater fines over coarse granitic gravels; $\mathrm{OG}=$ organic-rich granitic. 
Table 2. Physical characteristics of the terrace soils.

\begin{tabular}{|c|c|c|c|c|c|c|c|c|}
\hline \multirow{2}{*}{$\begin{array}{l}\text { Locality/ } \\
\text { profile }\end{array}$} & \multirow[t]{2}{*}{ Horizon } & \multirow{2}{*}{$\begin{array}{l}\text { Depth } \\
(\mathrm{cm})\end{array}$} & \multirow{2}{*}{$\begin{array}{c}\text { Gravel } \\
\text { W.- } \%\end{array}$} & \multirow{2}{*}{$\begin{array}{l}\text { Gravel } \\
\text { vol.- } \%\end{array}$} & \multicolumn{3}{|c|}{ Particle Size Distribution } & \multirow{2}{*}{$\begin{array}{c}\text { Bulk } \\
\text { density } \\
\left(\mathrm{g} / \mathrm{cm}^{3}\right)\end{array}$} \\
\hline & & & & & $\begin{array}{c}\text { Sand } \\
(2-0.5 \mathrm{~mm})\end{array}$ & $\begin{array}{c}\text { Silt } \\
(500-2 \mu)\end{array}$ & $\begin{array}{l}\text { Clay } \\
(<2 \mu)\end{array}$ & \\
\hline \multicolumn{9}{|c|}{$\begin{array}{l}\text { Little Popo Agie } \\
\text { - Red Canyon }\end{array}$} \\
\hline \multirow[t]{5}{*}{$\mathrm{RCT} 2$} & $\mathrm{~A}$ & $0-9$ & 0.6 & 0.3 & 27.2 & 49.2 & 23.6 & 1.2 \\
\hline & Bw1 & $9-21$ & 0.9 & 0.5 & 22.1 & 51.3 & 26.6 & 1.4 \\
\hline & Bw2k & $21-40$ & 0.1 & 0.1 & 25.0 & 49.1 & 25.9 & 1.5 \\
\hline & $\mathrm{CBk}$ & $40-60$ & 0.2 & 0.2 & 26.4 & 49.5 & 24.2 & 1.7 \\
\hline & $\mathrm{CK}$ & $60-90+$ & 1.0 & 0.7 & 25.9 & 63.2 & 10.9 & 1.8 \\
\hline \multirow[t]{5}{*}{ RCT3 } & A & $0-7$ & 14.2 & 7.0 & 39.1 & 44.9 & 16.1 & 1.2 \\
\hline & $\mathrm{AB}$ & $7-30$ & 13.2 & 7.4 & 37.3 & 42.2 & 20.5 & 1.4 \\
\hline & Bk1 & $30-50$ & 22.3 & 14.0 & 38.5 & 44.2 & 17.3 & 1.5 \\
\hline & $\mathrm{Bk} 2$ & $50-100$ & 32.1 & 23.3 & 60.6 & 34.7 & 4.7 & 1.7 \\
\hline & $2 \mathrm{C}$ & $100+$ & 25.8 & 19.1 & 55.0 & 36.0 & 8.0 & 1.8 \\
\hline \multirow{7}{*}{ RCT4 } & A & $0-10$ & 23.3 & 12.1 & 35.5 & 46.1 & 18.5 & 1.2 \\
\hline & Bw1 & $10-18$ & 14.7 & 8.4 & 40.9 & 41.6 & 17.5 & 1.4 \\
\hline & Bw2 & $18-30$ & 34.2 & 22.8 & 27.0 & 49.4 & 23.6 & 1.5 \\
\hline & Bk1 & $30-50$ & 33.9 & 21.3 & 22.5 & 47.0 & 30.5 & 1.4 \\
\hline & $\mathrm{Bk} 2$ & $50-100$ & 14.6 & 9.4 & 27.2 & 41.7 & 31.1 & 1.6 \\
\hline & $\mathrm{Ck}$ & $100-125$ & 54.3 & 44.7 & 48.1 & 44.2 & 7.8 & 1.8 \\
\hline & $\mathrm{C}$ & $125+$ & 49.4 & 39.8 & 55.4 & 36.2 & 8.4 & 1.8 \\
\hline \multirow[t]{5}{*}{ RCT5 } & A & $0-15$ & 6.6 & 3.1 & 32.4 & 47.1 & 20.4 & 1.2 \\
\hline & $\mathrm{AB}$ & $15-25$ & 30.6 & 17.8 & 52.1 & 30.5 & 17.4 & 1.3 \\
\hline & $\mathrm{Bk}$ & $25-40$ & 68.4 & 56.6 & 11.0 & 88.3 & 0.8 & 1.6 \\
\hline & $\mathrm{Bkm}$ & $40-80$ & 87.7 & 81.1 & -- & -- & -- & 1.6 \\
\hline & $\mathrm{Ck}$ & $80-200$ & 55.4 & 45.8 & 90.3 & 7.4 & 2.2 & 1.8 \\
\hline
\end{tabular}


- Lander

LWS-13-1

$\begin{array}{cccc}\text { A } & 0-13 & 12.8 & 6.2 \\ \text { Bt1 } & 13-23 & 3.8 & 2.2 \\ \text { Bt2 } & 23-32 & 10.4 & 6.2 \\ \text { Bk } & 32-120 & 37.0 & 28.5 \\ \text { BCk } & 120-150 & 27.2 & 18.4 \\ \text { C } & 150+ & 36.4 & 28.0\end{array}$

35.8

27.6

47.1

71.9

62.4

55.4

30.0

33.4

24.4

25.0
20.8

36.2

$\begin{array}{cc}34.2 & 1.2 \\ 39.0 & 1.5 \\ 28.5 & 1.5 \\ 3.0 & 1.8 \\ 16.8 & 1.6 \\ 8.4 & 1.8\end{array}$

SB

$\begin{array}{cc}\text { A } & 0-10 \\ \text { Bt } & 10-25 \\ \text { Bk1 } & 25-60 \\ \text { Bk2 } & 60-100 \\ \text { C } & 100+\end{array}$

$\begin{array}{cc}14.9 & 7.3 \\ 6.3 & 3.7 \\ 23.0 & 13.6 \\ 20.9 & 12.2 \\ 36.4 & 28.0\end{array}$

59.9

27.4

12.8

47.2

63.2

71.3

55.4

28.1

21.8

26.6

24.7

1.2

26.6

15.0

2.1

1.5
1.4

1.4

North Fork

PopoAgie

PB-13-1

$\begin{array}{cc}\text { A } & 0-5 \\ \text { AB } & 5-18 \\ \text { B } & 18-50 \\ \text { BC } & 50+\end{array}$

8.6

10.3

4.1

70.0

69.3

70.7

74.1

$\begin{array}{ll}15.9 & 9.7\end{array}$

31.8
31.5

$\begin{array}{ll}1.0 & 0.4\end{array}$

31.5
24.9

55.2

23.4

23.6

19.9

16.9

6.6
7.1
9.4

9.4

9.0

1.8

GalPD

$\begin{array}{cc}\text { A } & 0-25 \\ \text { Bw } & 25-45\end{array}$

0.4

58.1

58.8

10.1

51.6

9.7

23.5

30.3

14.5

1.2

70-90

90-120

C3

$120+$

GR-13-1

$\begin{array}{cc}\text { Ak } & 0-10 \\ \text { Btk } & 10-21 \\ \text { Bk } & 21-52 \\ \text { BCk } & 52-75 \\ \text { Ck } & 75+\end{array}$

25.7

42.9

43.5

53.1

37.8

11.5
25.4
31.7
37.4
25.6
3.4

70.7

68.7

72.2

89.5

85.9

24.9
22.7
20.4
8.1
9.2

25.1

66.4

25.1

$\begin{array}{ll}4.4 & 1.0 \\ 8.5 & 1.2 \\ 7.3 & 1.6 \\ 2.4 & 1.4 \\ 5.0 & 1.5 \\ 8.5 & 1.0\end{array}$

GR-13-2

A

$0-5$

$\begin{array}{ll}8.5 & 3.4\end{array}$

66.4

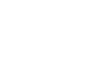




\begin{tabular}{|c|c|c|c|c|c|c|c|c|}
\hline & Bt1 & $5-18$ & 12.3 & 8.7 & 56.5 & 20.3 & 23.2 & 1.8 \\
\hline & Bt2 & $18-30$ & 13.9 & 9.8 & 57.5 & 19.7 & 22.9 & 1.8 \\
\hline & $\mathrm{Bk}$ & $30-70$ & 41.2 & 27.0 & 73.7 & 20.1 & 6.3 & 1.4 \\
\hline & $\mathrm{C} 2$ & $70-90$ & 38.6 & 13.1 & 92.9 & 5.0 & 2.1 & 0.6 \\
\hline & $\mathrm{C} 3$ & $90+$ & 36.4 & 12.1 & 94.6 & 3.2 & 2.2 & 0.6 \\
\hline PB-13-2 & A & $0-5$ & 9.7 & 3.2 & 68.8 & 24.9 & 6.3 & 0.8 \\
\hline & Bt1 & $5-13$ & 14.4 & 7.1 & 65.6 & 26.4 & 7.9 & 1.2 \\
\hline & $\mathrm{Bt} 2$ & $13-20$ & 15.4 & 9.3 & 69.1 & 25.4 & 5.4 & 1.5 \\
\hline & Bt3k & $20-30$ & 22.5 & 16.5 & 59.8 & 23.1 & 17.1 & 1.8 \\
\hline & $\mathrm{Bk} 1$ & $30-50$ & 43.8 & 37.0 & 76.1 & 15.2 & 8.7 & 2.0 \\
\hline & $\mathrm{Bk} 2$ & $50-90$ & 40.3 & 33.8 & 71.5 & 18.1 & 10.4 & 2.0 \\
\hline & $\mathrm{BCk} / \mathrm{CBk}$ & $90+$ & 27.9 & 19.0 & 84.7 & 13.0 & 2.3 & 1.6 \\
\hline
\end{tabular}


Table 3. Typical chemical characteristics of the terrace soils.

\begin{tabular}{|c|c|c|c|c|c|c|c|c|c|c|}
\hline Locality & Horizon & $\begin{array}{l}\text { Depth } \\
\mathrm{cm}\end{array}$ & $\begin{array}{c}\mathrm{pH} \\
\left(\mathrm{CaCl}_{2}\right)\end{array}$ & $\begin{array}{c}\text { inorg. C } \\
\mathrm{g} / \mathrm{kg}\end{array}$ & $\begin{array}{c}\text { org. C } \\
\mathrm{g} / \mathrm{kg}\end{array}$ & $\begin{array}{l}\text { org. N } \\
\mathrm{g} / \mathrm{kg}\end{array}$ & Org. $\mathrm{C} / \mathrm{N}$ & $\begin{array}{c}\mathrm{Fe}(\mathrm{ox})^{1)} \\
\mathrm{mg} / \mathrm{kg}\end{array}$ & $\begin{array}{c}\mathrm{Al}(\mathrm{ox})^{1)} \\
\mathrm{mg} / \mathrm{kg}\end{array}$ & $\begin{array}{c}\mathrm{Mn}(\mathrm{ox})^{1)} \\
\mathrm{mg} / \mathrm{kg}\end{array}$ \\
\hline \multicolumn{11}{|c|}{$\begin{array}{l}\text { Little PopoAgie } \\
\text { - Red Canyon }\end{array}$} \\
\hline \multirow[t]{5}{*}{ RCT2 } & A & $0-9$ & 7.31 & 5.0 & 35.7 & 9.26 & 3.9 & 350 & 647 & 158 \\
\hline & Bw1 & $9-21$ & 7.44 & 5.7 & 11.2 & 7.43 & 1.5 & 367 & 726 & 168 \\
\hline & Bw2k & $21-40$ & 7.39 & 5.9 & 9.2 & 6.24 & 1.5 & 327 & 689 & 172 \\
\hline & $\mathrm{CBk}$ & $40-60$ & 7.58 & 10.6 & 8.9 & 6.15 & 1.4 & 305 & 666 & 214 \\
\hline & $\mathrm{CK}$ & $60-90+$ & 7.68 & 21.3 & 4.0 & 5.93 & 0.7 & 316 & 612 & 158 \\
\hline \multirow[t]{5}{*}{ RCT3 } & $\mathrm{A}$ & $0-7$ & 7.52 & 6.3 & 18.5 & 6.62 & 2.8 & 223 & 589 & 323 \\
\hline & $\mathrm{AB}$ & $7-30$ & 7.58 & 10.9 & 13.2 & 6.32 & 2.1 & 182 & 529 & 264 \\
\hline & Bk1 & $30-50$ & 7.67 & 50.9 & 7.8 & 6.08 & 1.3 & 24 & 116 & 58 \\
\hline & $\mathrm{Bk} 2$ & $50-100$ & 7.92 & 49.0 & 2.8 & 4.57 & 0.6 & 76 & 207 & 92 \\
\hline & $2 \mathrm{C}$ & $100+$ & 7.93 & 35.3 & 0.3 & 4.70 & 0.1 & 270 & 10 & 186 \\
\hline \multirow[t]{7}{*}{ RCT4 } & $\mathrm{A}$ & $0-10$ & 7.39 & 10.1 & 19.5 & 5.32 & 3.7 & 375 & 1026 & 284 \\
\hline & Bw1 & $10-18$ & 7.53 & 18.6 & 14.5 & 4.97 & 2.9 & 227 & 774 & 174 \\
\hline & Bw2 & $18-30$ & 7.58 & 32.9 & 10.6 & 5.12 & 2.1 & 99 & 650 & 93 \\
\hline & Bk1 & $30-50$ & 7.62 & 53.2 & 7.3 & 4.32 & 1.7 & 53 & 451 & 59 \\
\hline & $\mathrm{Bk} 2$ & $50-100$ & 7.78 & 65.3 & 3.2 & 3.84 & 0.8 & 11 & 150 & 42 \\
\hline & $\mathrm{Ck}$ & $100-125$ & 8.03 & 48.3 & 2.7 & 3.68 & 0.7 & 120 & 283 & 105 \\
\hline & $\mathrm{C}$ & $125+$ & 7.80 & 22.0 & 0.6 & 3.58 & 0.2 & 70 & 43 & 265 \\
\hline \multirow[t]{5}{*}{ RCT5 } & A & $0-15$ & 7.64 & 23.4 & 11.2 & 4.84 & 2.3 & 202 & 534 & 223 \\
\hline & $\mathrm{AB}$ & $15-25$ & 7.57 & 39.3 & 16.2 & 4.49 & 3.6 & 123 & 336 & 107 \\
\hline & $\mathrm{Bk}$ & $25-40$ & 7.73 & 62.6 & 8.1 & 3.92 & 2.1 & 45 & 104 & 35 \\
\hline & $\mathrm{Bkm}$ & $40-80$ & 7.91 & 81.7 & 2.7 & 3.09 & 0.9 & 19 & 10 & 48 \\
\hline & $\mathrm{Ck}$ & $80-\sim 200$ & 7.99 & 43.8 & 2.3 & 2.54 & 0.9 & 91 & 130 & 132 \\
\hline
\end{tabular}


PopoAgie -

Lander

LWS-13-1

$\begin{array}{ccc}\text { A } & 0-13 & 7.70 \\ \text { Bt1 } & 13-23 & 7.69 \\ \text { Bt2 } & 23-32 & 7.71 \\ \text { Bk } & 32-120 & 7.70 \\ \text { BCk } & 120-150 & 7.89\end{array}$

$\begin{array}{ll}14.9 & 17.5 \\ 11.1 & 7.3\end{array}$

4.67

4.67
4.42

$\begin{array}{ll}3.7 & 523 \\ 1.7 & 413\end{array}$

440

$\begin{array}{lll}11.5 & 7.1 & 3.82\end{array}$

1.7
1.8

$\begin{array}{lll}40.5 & 1.9 & 3.28\end{array}$

0.6

172

$\begin{array}{lll}22.4 & 0.8 & 3.14\end{array}$

0.3

10

214

C

$150+$

SB

$\begin{array}{cccccccccc}\mathrm{A} & 0-10 & 7.37 & 0.7 & 10.8 & 3.66 & 2.9 & 285 & 347 & 206 \\ \mathrm{Bt} & 10-25 & 7.49 & 0.9 & 5.8 & 3.80 & 1.5 & 364 & 491 & 234 \\ \mathrm{Bk} 1 & 25-60 & 7.69 & 63.3 & 5.0 & 4.01 & 1.2 & 47 & 131 & 20 \\ \mathrm{Bk} 2 & 60-100 & 7.88 & 53.0 & 1.8 & 4.57 & 0.4 & 79 & 78 & 37 \\ \mathrm{C} & 100+ & & & & & & & & \end{array}$

\section{North Fork}

PopoAgie

PB-13-1

$\begin{array}{cccccccccc}\mathrm{A} & 0-5 & 6.40 & 0.6 & 20.6 & 2.82 & 7.3 & 1120 & 353 & 193 \\ \mathrm{AB} & 5-18 & 6.15 & 0.4 & 12.3 & 1.91 & 6.4 & 2267 & 335 & 260 \\ \mathrm{~B} & 18-50 & 6.80 & 0.1 & 7.1 & 1.02 & 7.0 & 770 & 418 & 190 \\ \mathrm{BC} & 50+ & 7.05 & 2.5 & 6.2 & 1.65 & 3.8 & 2557 & 435 & 185\end{array}$

GalPD

$\begin{array}{ccc}\text { A } & 0-25 & 7.50 \\ \text { Bw } & 25-45 & 7.60 \\ \text { BC } & 45-70 & 7.70 \\ \text { C } & 70-90+ & 7.78 \\ & 90-120 & 7.83 \\ & >120 & 7.80\end{array}$

$8.3 \quad 20.4$

6.01

2557

$435 \quad 185$

$\begin{array}{ccc}\text { Ak } & 0-10 & 7.30 \\ \text { Btk } & 10-21 & 7.35 \\ \text { Bk } & 21-52 & 7.60 \\ \text { BCk } & 52-75 & 7.50 \\ \text { Ck } & 75+ & 7.30\end{array}$

17.5

22.1

$20.4 \quad 6.01$

$3.4 \quad 400$

$558 \quad 155$

$\begin{array}{llllll}16.0 & 5.47 & 2.9 & 392 & 623 & 188\end{array}$

$\begin{array}{llllll}7.1 & 5.02 & 1.4 & 218 & 236 & 211\end{array}$

$\begin{array}{lllllll}15.4 & 1.5 & 3.47 & 0.4 & 10 & 241 & 337\end{array}$

$\begin{array}{lllllll}12.9 & 1.5 & 3.96 & 0.4 & 10 & 164 & 506\end{array}$

GR-13-1

$\begin{array}{ccccccc}0.4 & 16.3 & 5.26 & 3.1 & 591 & 805 & 273 \\ 0.1 & 15.5 & 4.75 & 3.3 & 258 & 1073 & 219 \\ 28.1 & 8.2 & 3.83 & 2.1 & 165 & 434 & 111 \\ 18.6 & 2.3 & 2.19 & 1.0 & 166 & 100 & 80 \\ 15.3 & 4.1 & 2.51 & 1.6 & 168 & 100 & 73\end{array}$




\begin{tabular}{ccccccccccc} 
GR-13-2 & A & $0-5$ & 6.18 & 0.0 & 10.1 & 3.57 & 2.8 & 385 & 287 & 149 \\
& Bt1 & $5-18$ & 6.53 & 1.4 & 6.7 & 3.74 & 1.8 & 271 & 893 & 100 \\
& Bt2 & $18-30$ & 6.80 & 2.3 & 5.9 & 3.77 & 1.6 & 130 & 1073 & 45 \\
& Bk & $30-70$ & 7.54 & 29.5 & 9.9 & 3.95 & 2.5 & 48 & 669 & 3 \\
& C2 & $70-90$ & 7.74 & 54.4 & 5.2 & 3.93 & 1.3 & 107 & 33 & 7 \\
PB-13-2 & C3 & $90+$ & 7.72 & 6.5 & 1.1 & 3.12 & 0.3 & 581 & 116 & 29 \\
& & & & & & & & & \\
& A & $0-5$ & 7.50 & 1.4 & 21.7 & 4.46 & 4.9 & 350 & 505 & 251 \\
& Bt1 & $5-13$ & 7.30 & 1.0 & 14.4 & 3.09 & 4.7 & 291 & 514 & 229 \\
& Bt2 & $13-20$ & 7.50 & 7.0 & 14.3 & 2.38 & 6.0 & 180 & 568 & 162 \\
& Bt3k & $20-30$ & 7.65 & 19.8 & 14.8 & 3.15 & 4.7 & 138 & 412 & 96 \\
& Bk1 & $30-50$ & 7.60 & 58.1 & 12.4 & 2.82 & 4.4 & 25 & 46 & 26 \\
& Bk2 & $50-90$ & 7.20 & 56.4 & 5.4 & 2.35 & 2.3 & 24 & 40 & 12 \\
& BCk / CBk & $90+$ & 7.65 & 22.6 & 2.6 & 1.75 & 1.5 & 114 & 40 \\
\hline
\end{tabular}

${ }^{1)} \mathrm{Ox}=$ oxalate-extractable fraction 
Table 4. Overview of the main soil minerals (obtained from XRD and DRIFT measurements) in the fraction $<32 \mu \mathrm{m}(\mathrm{clay}+$ fine silt)

\begin{tabular}{|c|c|c|c|c|c|c|c|c|c|c|c|}
\hline Site (age) & Horizon & Quartz & Orthoclase & Albite & Mica & Vermiculite & Chlorite & Calcite & Dolomite & Kaolinite & Hematite \\
\hline \multirow[t]{2}{*}{ PB-13-1 (Holocene) } & $\mathrm{A}$ & $\mathrm{xxx}$ & $\mathrm{xx}$ & $\mathrm{xx}$ & $\mathrm{x}$ & & & & $?$ & $\mathrm{x}$ & $?$ \\
\hline & $\mathrm{AB}$ & $\mathrm{xxx}$ & $\mathrm{x}$ & $\mathrm{x}$ & $\mathrm{x}$ & $\mathrm{x}$ & $?$ & $?$ & $?$ & $\mathrm{x}$ & $?$ \\
\hline \multirow[t]{4}{*}{ GR-13-1 (160 ky) } & $\mathrm{Ak}$ & $\mathrm{xxx}$ & $\mathrm{x}$ & $\mathrm{x}$ & $\mathrm{x}$ & $\mathrm{x}$ & & $\mathrm{xx}$ & $\mathrm{x}$ & $\mathrm{x}$ & $(\mathrm{x})$ \\
\hline & Btk & $\mathrm{xxx}$ & $\mathrm{x}$ & $\mathrm{x}$ & $\mathrm{x}$ & $\mathrm{x}$ & & $\mathrm{xx}$ & $\mathrm{x}$ & $\mathrm{x}$ & $(\mathrm{x})$ \\
\hline & $\mathrm{Bk}$ & $\mathrm{xxx}$ & $\mathrm{x}$ & $\mathrm{x}$ & $\mathrm{x}$ & $\mathrm{x}$ & & $\mathrm{xx}$ & $?$ & & \\
\hline & $\mathrm{Ck}$ & $\mathrm{xx}$ & $\mathrm{x}$ & $\mathrm{x}$ & $\mathrm{x}$ & $?$ & & $\mathrm{xxx}$ & $\mathrm{xx}$ & $\mathrm{x}$ & $?$ \\
\hline \multirow[t]{6}{*}{ PB-13-2 (660 ky) } & A & $\mathrm{xxx}$ & $\mathrm{xx}$ & $\mathrm{xx}$ & $\mathrm{x}$ & $\mathrm{x}$ & & $\mathrm{x}$ & $?$ & $\mathrm{x}$ & (x) \\
\hline & Bt1 & $\mathrm{xxx}$ & $\mathrm{xx}$ & $\mathrm{xx}$ & $\mathrm{xx}$ & $\mathrm{x}$ & & $\mathrm{xx}$ & $?$ & $\mathrm{x}$ & $(\mathrm{x})$ \\
\hline & $\mathrm{Bt} 2$ & $\mathrm{xxx}$ & $\mathrm{x}$ & $\mathrm{xx}$ & $\mathrm{x}$ & $\mathrm{x}$ & & $\mathrm{xxx}$ & $\mathrm{x}$ & $\mathrm{x}$ & $(\mathrm{x})$ \\
\hline & $\mathrm{Bt} 3 \mathrm{k}$ & $\mathrm{xxx}$ & $\mathrm{x}$ & $\mathrm{x}$ & $\mathrm{x}$ & $?$ & & $\mathrm{xxx}$ & $?$ & $\mathrm{x}$ & $(\mathrm{x})$ \\
\hline & Bk1 & $\mathrm{xx}$ & $\mathrm{x}$ & $\mathrm{x}$ & $\mathrm{x}$ & $?$ & & $\mathrm{xxx}$ & $\mathrm{x}$ & $\mathrm{x}$ & $?$ \\
\hline & $\mathrm{BCk} / \mathrm{CBk}$ & $\mathrm{xx}$ & $\mathrm{x}$ & $\mathrm{x}$ & $?$ & $\mathrm{x}$ & & $\mathrm{xxx}$ & $\mathrm{xx}$ & $(\mathrm{x})$ & $(\mathrm{x})$ \\
\hline
\end{tabular}

Concentration indications

? questionable

(x) traces

$\mathrm{x}$ low amount

xx moderate amount

$\mathrm{xxx}$ high amount 
Table 5. Stocks and interval-accumulation rates for pedogenic $\mathrm{CaCO}_{3}$.

\begin{tabular}{lcccc}
\hline Terrace age & $\begin{array}{c}\mathrm{CaCO}_{3} \\
\text { stocks }\end{array}$ & $\begin{array}{c}\text { Average } \\
\text { accumulation rates } \\
\text { (linear trend) } \\
\mathrm{g} / \mathrm{m}^{2} / \mathrm{y}\end{array}$ & $\begin{array}{c}\text { Time range } \\
\text { (for accumulation } \\
\text { rate) }\end{array}$ & $\begin{array}{c}\text { Interval- } \\
\text { Accumulation rates }\end{array}$ \\
\hline $20 \mathrm{ky}$ & 16 & 0.79 & $0-20 \mathrm{ky}$ & $\mathrm{g} / \mathrm{m}^{2} / \mathrm{y}$ \\
$160 \mathrm{ky}$ & 314 & 1.96 & $20-160 \mathrm{ky}$ & 0.79 \\
$260 \mathrm{ky}$ & 393 & 1.51 & $160-260 \mathrm{ky}$ & 2.13 \\
$660 \mathrm{ky}$ & 469 & 0.71 & $260-660 \mathrm{ky}$ & 0.79 \\
\hline
\end{tabular}


Appendix A
Click here to download Background dataset for online publication only: Appendix_1.docx (1)

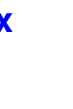

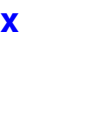

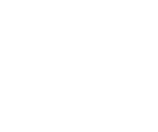
列 $\sqrt{20}$

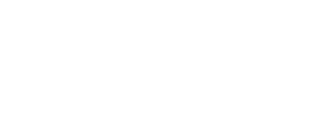
. . . . . . . . . . . . . . . . (1)

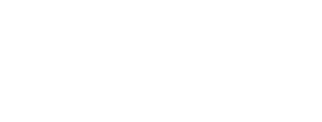

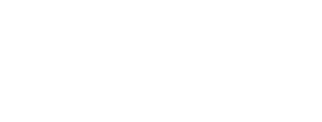
.

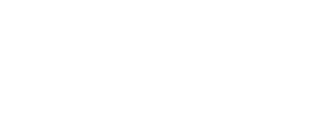

